\title{
New synthetic routes to highly-extended tetrathiafulvalenes
}

\author{
Piétrick Hudhomme,* Marc Sallé,* Nicolas Gautier, Ahmed Belyasmine, \\ and Alain Gorgues
}

Laboratoire de Chimie et Ingénierie Moléculaire des Matériaux d'Angers (CIMMA),

Groupe Synthèse Organique et Matériaux Fonctionnels,

UMR CNRS 6200, Université d'Angers, 2 Bd Lavoisier, F-49045 Angers, France

E-mail:pietrick.hudhomme@univ-angers.fr,marc.salle@univ-angers.fr

\section{Dedicated to Prof. Armand LATTES on the occasion of his $50^{\text {th }}$ anniversary of teaching and research activities and for his involvement as a President of the "Société Française de Chimie"}

\begin{abstract}
Various synthetic routes to highly extended tetrathiafulvalene (TTF) derivatives are presented. They generally involve a (poly)olefination reaction in the last step, thanks to Wittig-type or Horner-Wadsworth-Emmons (HWE) reactions. Two complementary strategies have been carried out by reacting a (poly)formyl-TTF with a phosphorous (P-ylide or phosphonate) reagent, or on the contrary, by the preparation of (poly)phosphonate-TTF derivatives prone to react with aldehydes. An X-ray structural determination of one of these systems confirms the high $\pi$ extension of such resulting TTF derivatives.
\end{abstract}

Keywords: Tetrathiafulvalene, Magtrieve ${ }^{\mathrm{TM}}$, Wittig, HWE olefination, $\pi$-conjugation

\section{Introduction}

There is currently an important interest in achieving the syntheses of tetrathiafulvalene (TTF) derivatives in order to improve the electroconducting properties of the corresponding chargetransfer complexes or cation radical salts. ${ }^{1}$ It is well established that stabilization of the metallic state of these materials may be reached by increasing their dimensionality, ${ }^{2}$ which can be achieved chemically by subtle molecular engineering around the electroactive TTF framework. ${ }^{3,4,5}$ An active trend consists in the synthesis of highly extended and/or S-rich TTF analogues. ${ }^{5}$ The effects which are expected from such extended $\pi$-donating molecules are : a) the enhancement of the dimensionality, in the solid state, thanks to the multiplication of sulfur atoms in the molecular structure allowing multi intra- and inter-chain S...S contacts; b) strong intermolecular interactions in the stacking mode of related materials, due to the lowering of the 
charge density in the oxidized states and consequently due to a decrease of the coulombic repulsions between the positively charged oxidized neighbours; c) the lowering of the intramolecular coulombic repulsions in the oxidized species which may also provide an easy access to unusual stable multicationic species upon full oxidation, giving rise to organic salts of unconventional stoichiometries; d) finally, a higher $\pi$-donor ability in solution compared to parent TTF itself. TTF dimers and higher oligomers, in which the TTF units are linked by conjugated $\pi$-systems, were also identified as a possibility to increase the dimensionality of corresponding materials. ${ }^{6}$ These systems display multi-stage redox behavior thanks to intramolecular through-bond or through-space interactions between TTF units.

Considering the different modes of extension of the TTF framework, the retrosynthetic methodology involves olefination reactions using Wittig-type reactions under basic conditions with various ylides or Horner-Wadsworth-Emmons (HWE) reactions with phosphonate anions (Scheme 1). ${ }^{7}$ Therefore, there is a need for a controlled access to mono- or poly-formyl TTF derivatives, prone to undergo olefinations with various P-ylids or phosphonate anions (Route 1). Alternatively, similar highly extended systems can be built from the reciprocal strategy, i.e the reaction of TTF-phosphonates with aldehydes (Route 2).

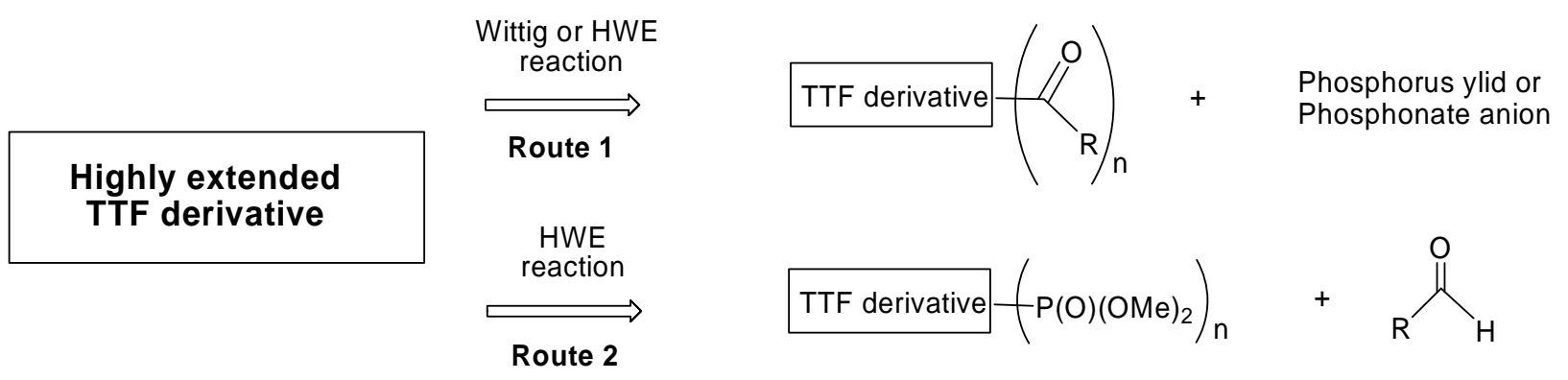

\section{Scheme 1}

In this work we will present successively our efforts concerning the preparation of (poly)formyl TTF derivatives 1-4 (Scheme 2), the access to TTF-phosphonate derivatives, and finally we will present different families of extended TTF derivatives obtained by (poly)olefinations using these reagents.

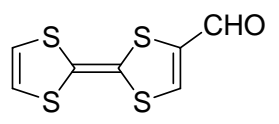

1

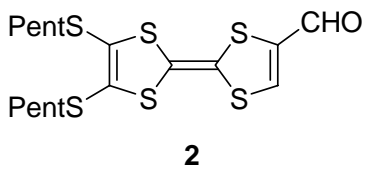

2<smiles>O=CC1=C(C=O)SC(=C2SC3=C(SCCS3)S2)S1</smiles>

3<smiles>O=CC1=C(C=O)SC(=C2SC(C=O)=C(C=O)S2)S1</smiles>

4

Scheme 2 


\section{Results and Discussion}

\section{Synthesis of the mono and polyformyl-TTF derivatives}

TTF derivative 1 was prepared according to the described procedure, ${ }^{8}$ by formylation of TTF using LDA and N-methylformanilide.

Synthesis of monoformyl TTF 2 was carried out according to a multi-step strategy (Scheme 3). The initial trimethylphosphite-mediated cross-coupling of the two corresponding 2(thi)oxo-1,3-dithiole moieties 5 and 6 afforded 2,3-bis(methoxycarbonyl)TTF 7 in $62 \%$ yield, according to a known procedure. ${ }^{9}$ Further monodecarboxymethoxylation to 8 was cleanly achieved in $96 \%$ yield by treatment with $\mathrm{LiBr}$ salt in refluxing DMF. Attempts to reduce selectively, using DiBAl-H, the ester functionality into the corresponding aldehyde failed. In fact, we could obtain efficiently in $92 \%$ yield the mono(hydroxymethyl)TTF 9. At this stage, different oxidizing reagents were tested such as $\mathrm{MnO}_{2}{ }^{10}$ or $\mathrm{SeO}_{2}{ }^{11}$ since these reagents have already been used successfully for the conversion of hydroxymethyl-TTFs into the corresponding aldehyde. In our case, best results were obtained taking advantage of the easy to handle Magtrieve ${ }^{\mathrm{TM}}\left(\mathrm{CrO}_{2}\right)$ reagent. ${ }^{12}$ Thus, transformation of the hydroxymethyl group to the formyl group (compound 2) was achieved in 65\% yield using this reagent .
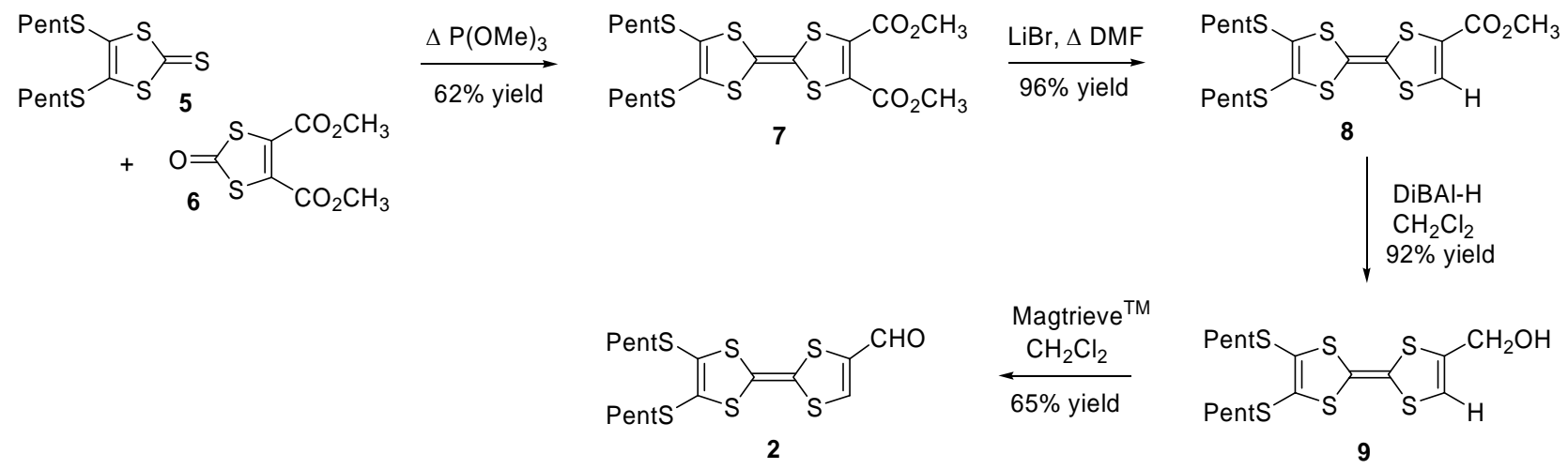

\section{Scheme 3}

Two different routes were used to reach bis(formyl) TTF derivative 3 (Scheme 4). The first one involves a $\mathrm{Co}_{2}(\mathrm{CO})_{8}$ mediated cross-coupling of compound $\mathbf{1 0}$ with thione $\mathbf{1 1}^{13}$ bearing vicinal formyl and di(ethyl)acetal functions. Yields are rather low in this desulfuration-coupling step, but the resulting TTF derivative 12 could be transformed in reasonable yields into the corresponding bis(formyl) derivative 3 by simple formolysis. Alternatively, we synthesized in good yield 2,3-bis(methoxycarbonyl)TTF 13 according to the literature. ${ }^{9,14}$ As described above in the monofunctionalized series (to compound 2), selective reduction of $\mathbf{1 3}$ into 3 could not be achieved. Instead, reduction into the corresponding bis(hydroxymethyl)TTF 14 and subsequent smooth oxidation with Magtrieve ${ }^{\mathrm{TM}}$ reagent proved to be the best alternative strategy to reach 
bis(formyl)TTF 3 . The latter was obtained in 50\% yield after separation from a mixture consisting in the monoformyl intermediate and various overoxidation products.

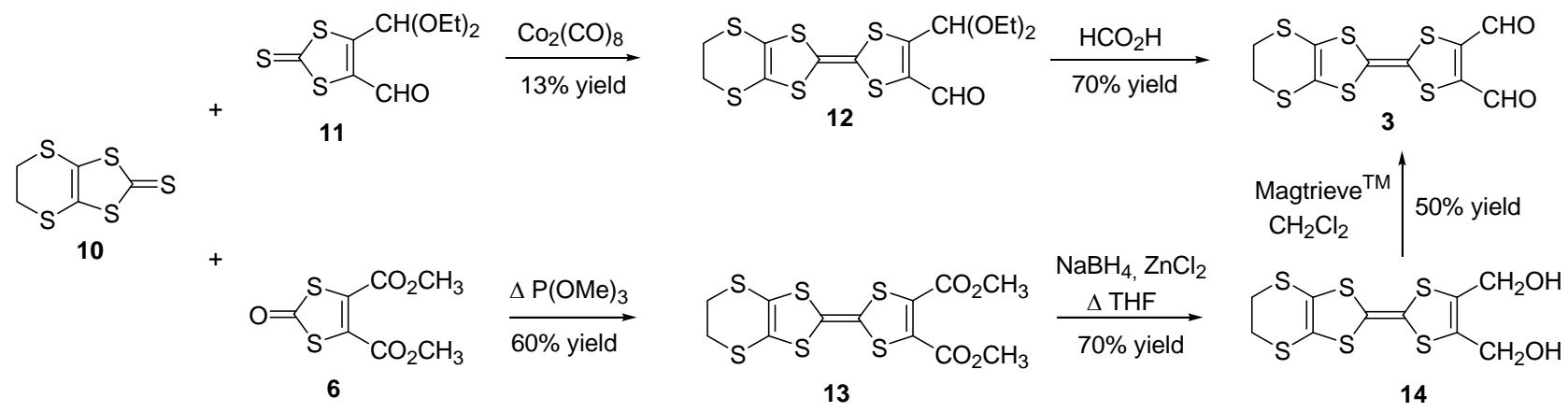

\section{Scheme 4}

Tetraformyl-TTF 4 was prepared according to literature from the $\mathrm{Co}_{2}(\mathrm{CO})_{8}$ mediated selfcoupling of $\mathbf{1 1}$ and subsequent formolysis. ${ }^{13}$

\section{Synthesis of TTF-phosphonate derivatives}

It is now clearly established that the powerful synthetic potential of phosphonate derivatives is the source of varied applications (Scheme 5). Indeed their higher nucleophilic character compared to ylids was exploited to achieve the required olefination of conjugated aldehyde to reach TTF vinylogue derivatives (reaction $I$, Scheme 5). ${ }^{15}$ The HWE reaction could be performed on $p$-benzoquinone after a decrease of its accepting quinonic character using the Yamashita's methodology of protection-deprotection with cyclopentadiene (reaction II). ${ }^{16}$ Another utilization of the phosphonate anion was recently shown with the creation of the central TTF double bond directly from the 2-oxo-1,3-dithiole moiety (reaction III). ${ }^{17}$ The high reactivity of the phosphonate anion was finally demonstrated with the synthesis of spatial extended fused T-shaped TTF which involved a three-fold HWE olefination process (reaction $I V$ ). ${ }^{18}$

We were interested in developing new phosphonate reagents derived from 1,3-dithiole or TTF moieties to reach highly sulfur-rich extended TTF-based architectures. Consequently, we now present a new approach to extend the TTF framework using HWE-type reagents (compounds 15-18). These reagents associate in their structure (dimethylphosphono)methyl groups to the 1,3-dithiole or TTF units (Scheme 6). 
<smiles>[R]C1=C([R])SC(=C2Sc3cc4c(=C5SC([R])=C([R])S5)ccc(=C5SC([R])=C([R])S5)c4cc3S2)S1</smiles>
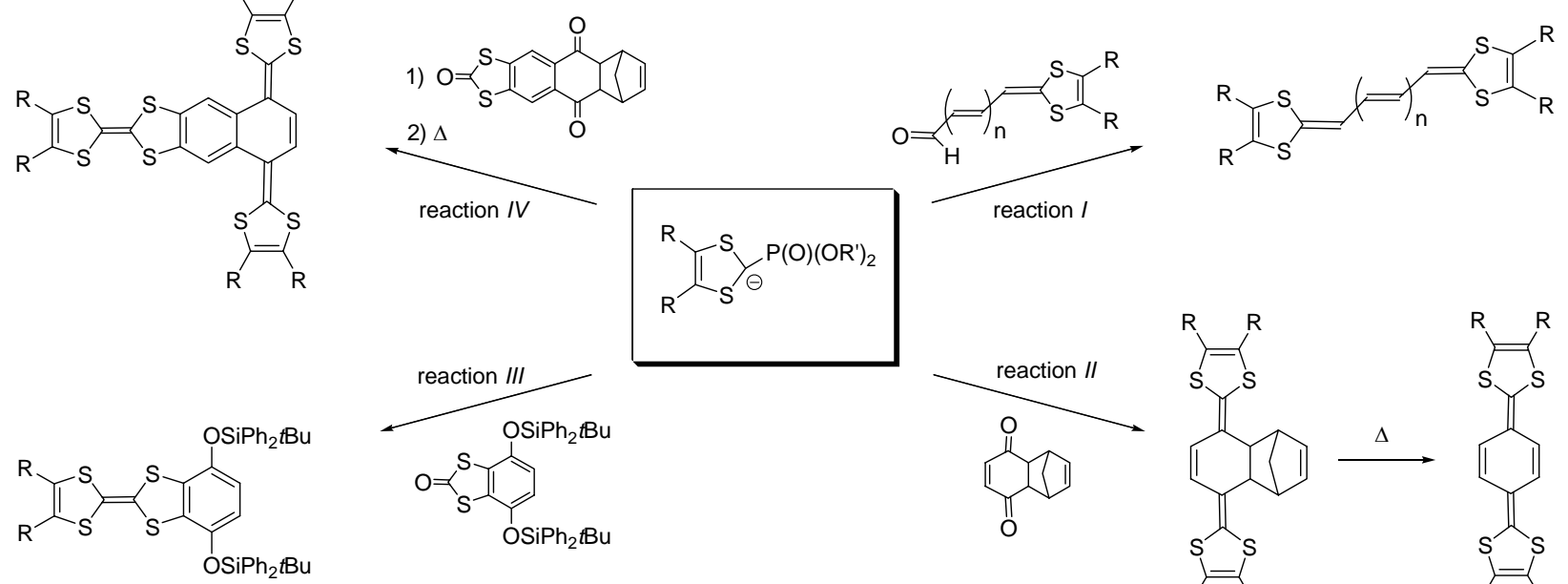

\section{Scheme 5}

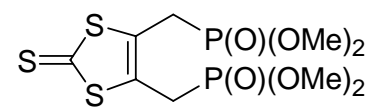

15

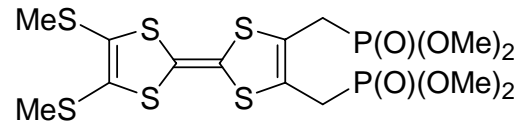

16

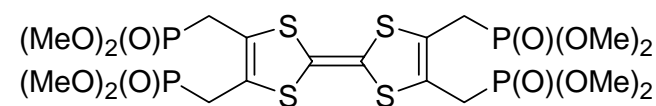

17

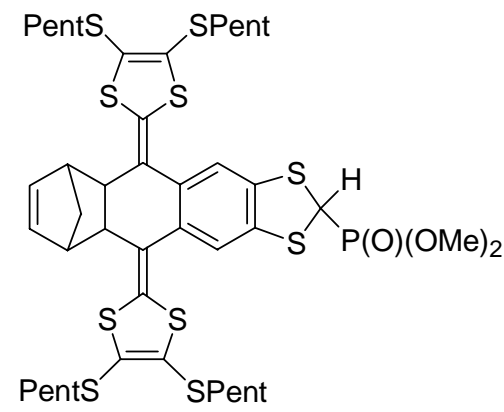

18

\section{Scheme 6}

The reactivity of the vicinal bis(bromomethyl) group has been demonstrated with the possibility of generating the corresponding diene by reductive elimination ${ }^{18,19}$ or to perform its transformation into the pyrrolo group. ${ }^{20}$ The versatile synthetic reactivity of this group is now extended to the Arbuzov-type reaction to reach bis 15, 16 or tetrakis 17 phosphonate derivatives respectively. Considering this methodology, this vicinal bis(bromomethyl) group can act as a dicationic synthetic equivalent (Scheme 7).

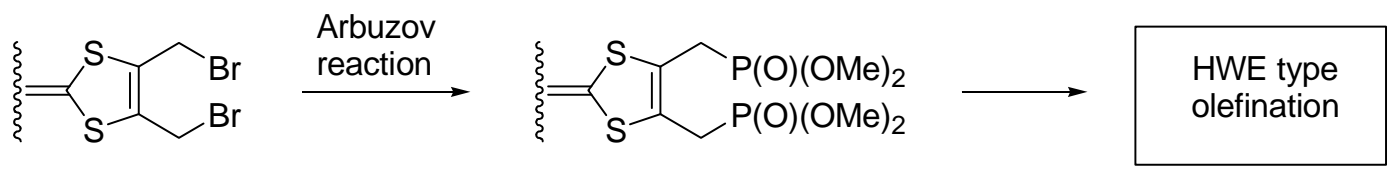

\section{Scheme 7}


The Arbuzov reaction was achieved by treatment of 2,3-bis(bromomethyl)-2-thioxo-1,3dithiole $\mathbf{1 9}^{14}$ or TTF $\mathbf{2 0}^{21}$ in refluxing trimethylphosphite. The corresponding phosphonate derivatives 15 and 16 were isolated in $46 \%$ and 40\% yield respectively. Unfortunately, starting from tetrakis(bromomethyl)TTF $2 \mathbf{1}^{21}$ and using the same experimental procedure, we were not able to obtain the tetraphosphonate $\mathbf{1 7}$ (Scheme 8).

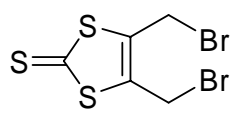

19

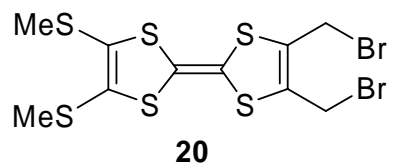<smiles>BrCC1=C(CBr)SC(=C2SC(CBr)=C(CBr)S2)S1</smiles>

21

$$
\underset{46 \% \text { yield }}{\stackrel{\Delta \mathrm{P}(\mathrm{OMe})_{3}}{\longrightarrow}}
$$

$\underset{40 \% \text { yield }}{\stackrel{\Delta \mathrm{P}(\mathrm{OMe})_{3}}{\longrightarrow}}$

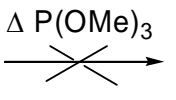<smiles>COPCc1sc(=S)sc1C[Pb]OC</smiles>

15
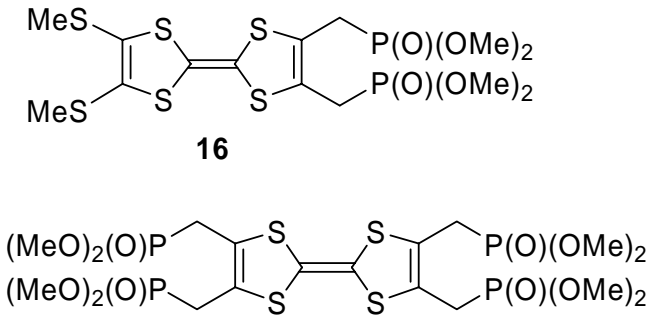

17

\section{Scheme 8}

To circumvent this difficulty, another synthetic method was developed to reach compound 17. Methylation of $\mathbf{1 5}$ with methyl triflate followed by reduction with sodium borohydride afforded compound 22 in an overall 93\% yield. The 1,3-dithiolium salt 23 was produced in quantitative yield by dethiomethylation with tetrafluoroboric acid in acetic anhydride. Treatment with an excess of triethylamine afforded TTF 17 by carbenoid coupling in $81 \%$ yield (Scheme 9).

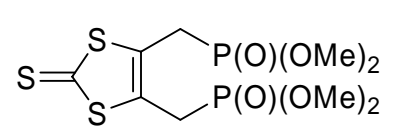

15

1) $\mathrm{CF}_{3} \mathrm{SO}_{3} \mathrm{Me}$

$\frac{\text { 2) } \mathrm{NaBH}_{4}, i \mathrm{PrOH} / \mathrm{CH}_{3} \mathrm{CN}}{93 \% \text { yield }}$

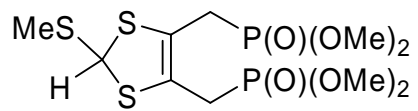

22

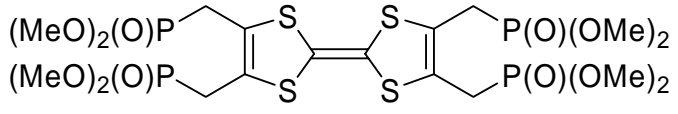

17

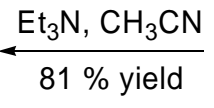

$\mathrm{BF}_{4}^{\ominus}$

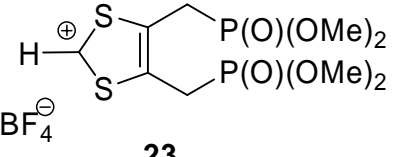

23

\section{Scheme 9}




\section{Application to the synthesis of various families of extended-TTF derivatives $p-N, N$ -} Dimethylaminostyrenyl- TTF derivatives 25, 26 and 27

The $N, N$-dimethylaminostyrenyl moiety is a well-known electrodonating system. We have introduced this group on the periphery of the TTF framework in order to enhance the $\pi$-donating ability of the resulting extended system. The general synthetic strategy involved a Wittig-type mono-, di- or tetraolefination between the P-ylide generated using tBuOK from $24^{22}$ and TTF aldehyde 1, 3 or 4 (Scheme 10). Corresponding highly extended systems 25, 26 and 27 were isolated in good yields $(>75 \%)$, if one considers that up to four simultaneous olefinations took place in the case of 27. Only the $E$ configuration was observed by ${ }^{1} \mathrm{H}-\mathrm{NMR}$ analysis for each double bond created.

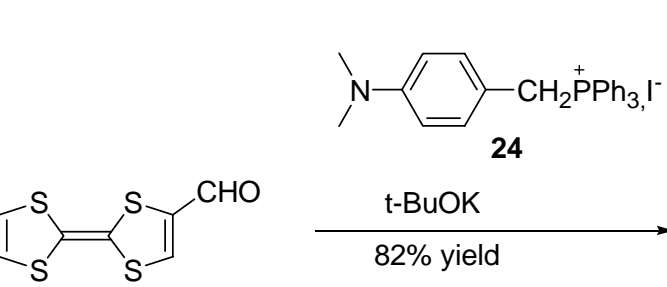

1

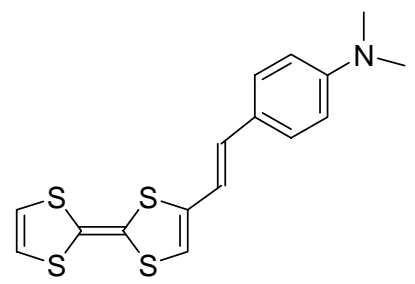

25

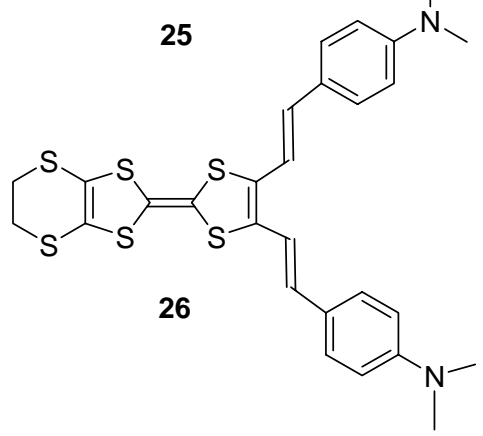<smiles>O=CC1=C(C=O)SC(=C2SC3=C(SCCS3)S2)S1</smiles>

24, t-BuOK

$75 \%$ yield

3

26
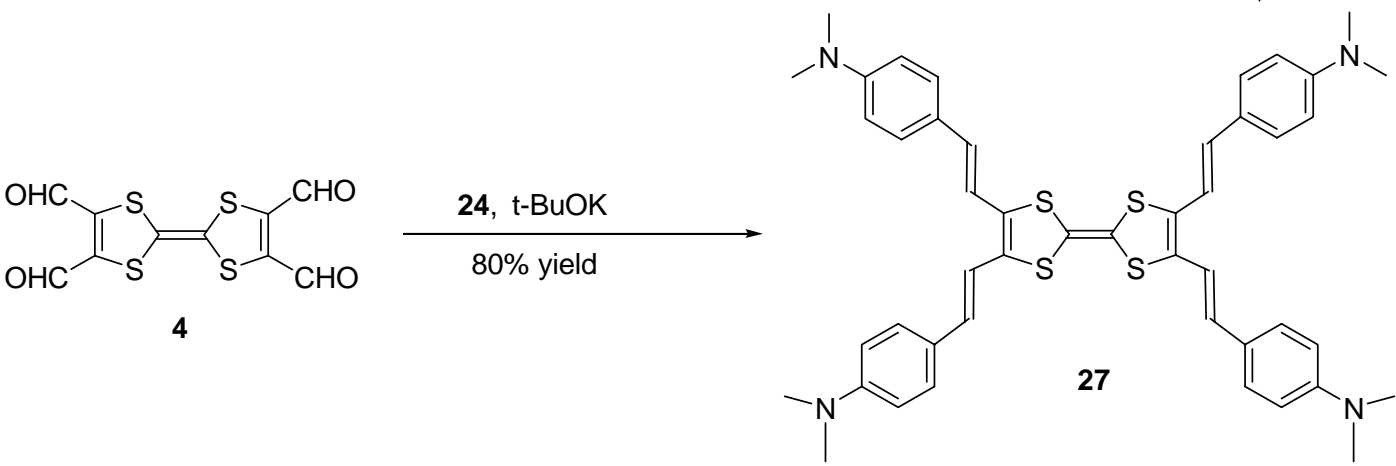

\section{Scheme 10}

Single crystals of $\mathbf{2 6}$ could be grown as orange needles from a dichloromethane - methanol mixture, and the X-ray structure was determined (Figure 1). It appears that in the solid state, compound 26 presents a conformation close to planarity, giving rise to a highly extended $\pi$ system where the different units are therefore conjugated. The configuration of both double bonds generated during the Wittig olefination process is confirmed to be E. A transoid 
conformation is observed for both $p$-N,N-dimethylamino styrenyl moieties relatively to the TTF framework, as expected from the steric demand generated by the vicinity of these groups.

a)

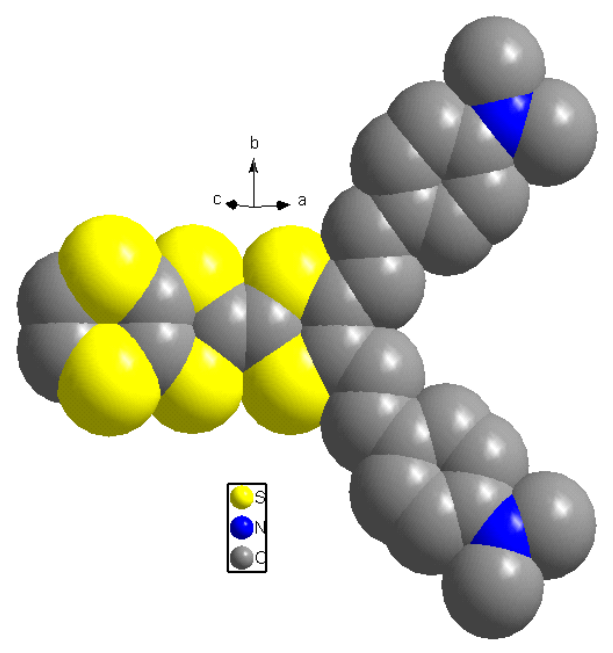

b)

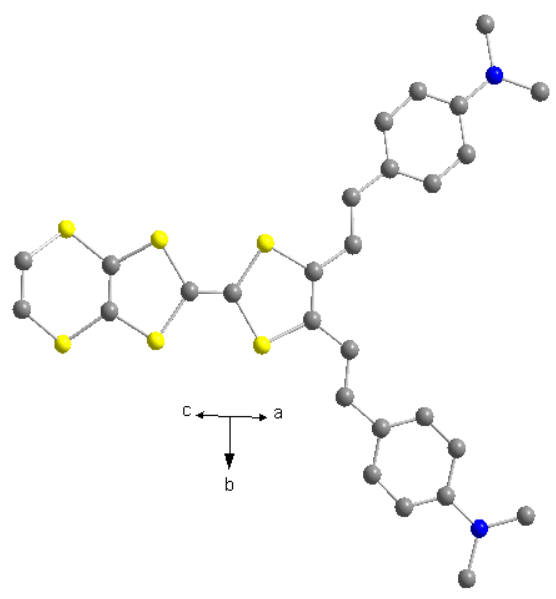

c)

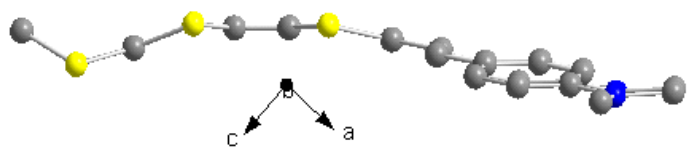

Figure 1 : Molecular structure of $\mathbf{2 6}$ according to X-ray diffraction: a) space-filling model; b) $2 \mathrm{D}$-extension of the $\pi$-system; c) projection onto the $a c$ plane.

\section{Styrenyl- TTF derivatives 28, 29 and 30}

The reactivity of phosphonates 15-17 was first evaluated by deprotonation followed by olefination reaction using benzaldehyde as the electrophile. The corresponding 2-thioxo-1,3dithiole 28 and TTFs 29-30 derivatives conjugated with styrenyl groups were isolated in satisfactory yields (Scheme 11). As for the above N,N-dimethylstyrenyl analogues 25-27, which were prepared via the reverse strategy $\left(\mathrm{TTF}-(\mathrm{CHO})_{\mathrm{n}}+\right.$ ylide), it should be noted that ${ }^{1} \mathrm{H}$ NMR spectroscopy of compounds 28-30 was consistent with the $E$ configuration for all double bonds created.<smiles>S=c1sc(/C=C/c2ccccc2)c(/C=C/c2ccccc2)s1</smiles><smiles>CSC1=C(SC)SC(=C2SC(/C=C/c3ccccc3)=C(/C=C/c3ccccc3)S2)S1</smiles>

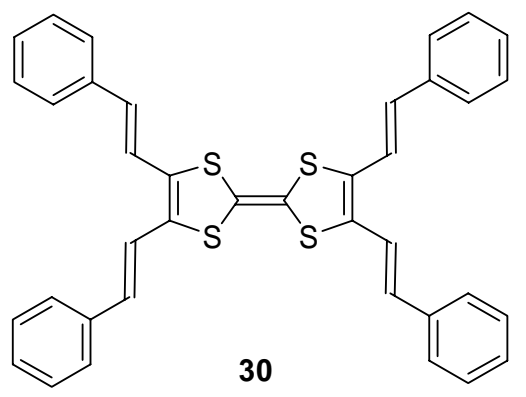

Scheme 11 
This reactivity was extended to novel conjugated dimeric and trimeric TTF. Deprotonation using $t \mathrm{BuOK}$ or $\mathrm{BuLi}$ followed by the addition of adequately substituted monoformylTTF 2 led to the corresponding dimeric TTF 31 and trimeric TTF 32 (Scheme 12). Yields in the HWE reaction were notably improved when $t \mathrm{BuOK}$ was added to a solution of electrophilic aldehyde 2 and diphosphonate 15 or 16 at $0^{\circ} \mathrm{C}$ (31:79\%; 32 : 55\% yields) instead of generating first the anion of diphosphonate $\mathbf{1 6}$ followed by the addition of the aldehyde 2 .
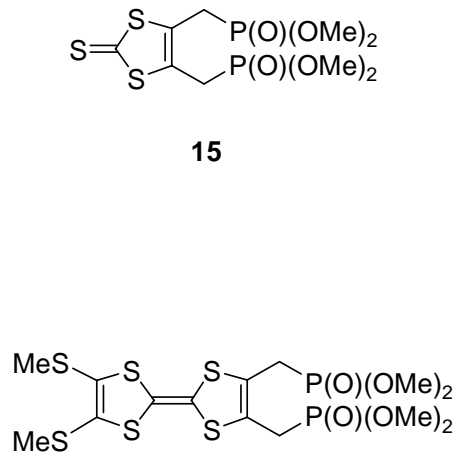

16

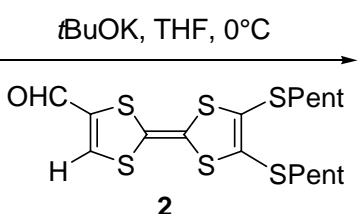

2

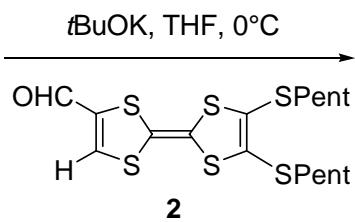

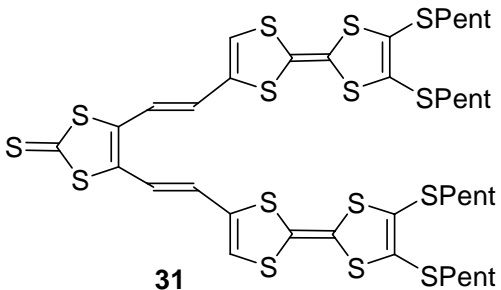

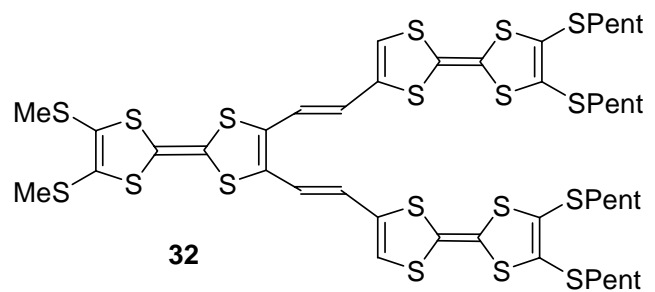

Scheme 12

The synthesis of phosphonate 18 started from compound $\mathbf{1 9}^{14}$ (Scheme 13). Subsequent reductive elimination carried out using $\mathrm{Et}_{4} \mathrm{~N}^{+} \mathrm{I}^{-}$afforded the resulting transient diene 33 which reacted with $p$-benzoquinone according to a [4+2] Diels-Alder cycloaddition. Aromatization of the cycloadduct into compound $\mathbf{3 4}$ was carried out by treatment with DDQ. In order to perform further olefinations, it was necessary to decrease the accepting quinonic character of $\mathbf{3 4}$. The methodology of protection-deprotection developed by Yamashita using Diels-Alder cycloaddition with cyclopentadiene was applied. ${ }^{16}$ Consequently, we submitted the raw material to a [4+2] cycloaddition by treatment with cyclopentadiene in THF. Compound 35 was then isolated as yellow crystals in 59\% yield (calculated from 19) after purification by silica gel column chromatography. HWE olefination of both carbonyl functionalities of compound 35 was carried out using an excess of phosphonate 36 in the presence of $n$-BuLi. Resulting bis-olefinated product 37 could be isolated as an analytically pure compound in $93 \%$ yield after precipitation with $\mathrm{MeOH}$. Treatment of 2-thioxo-1,3-dithiole derivative 37 with trimethylphosphite afforded the expected TTF 38 resulting from the self-coupling reaction accompanied with phosphonate 18 according to a phenomenon appearing under high dilution conditions. ${ }^{23} \mathrm{We}$ noted also the transformation of the thioxo derivative onto the oxo analogue $39 .^{24}$ These three compounds were easily separated by silica gel column chromatography affording successively TTF derivative $\mathbf{3 8}$, then the oxo derivative 39 (petroleum ether/ $\mathrm{CH}_{2} \mathrm{Cl}_{2}: 7 / 3$ ) and finally, phosphonate $\mathbf{1 8}$ (petroleum 
ether/EtOAc : 1/1). Corresponding yields depending on experimental conditions are reported in Table 1. Moreover, note that we were able to transform the oxo derivative $\mathbf{3 9}$ into the expected phosphonate 18 in $41 \%$ yield (with only traces of TTF) using a diluted solution of trimethylphosphite in toluene.
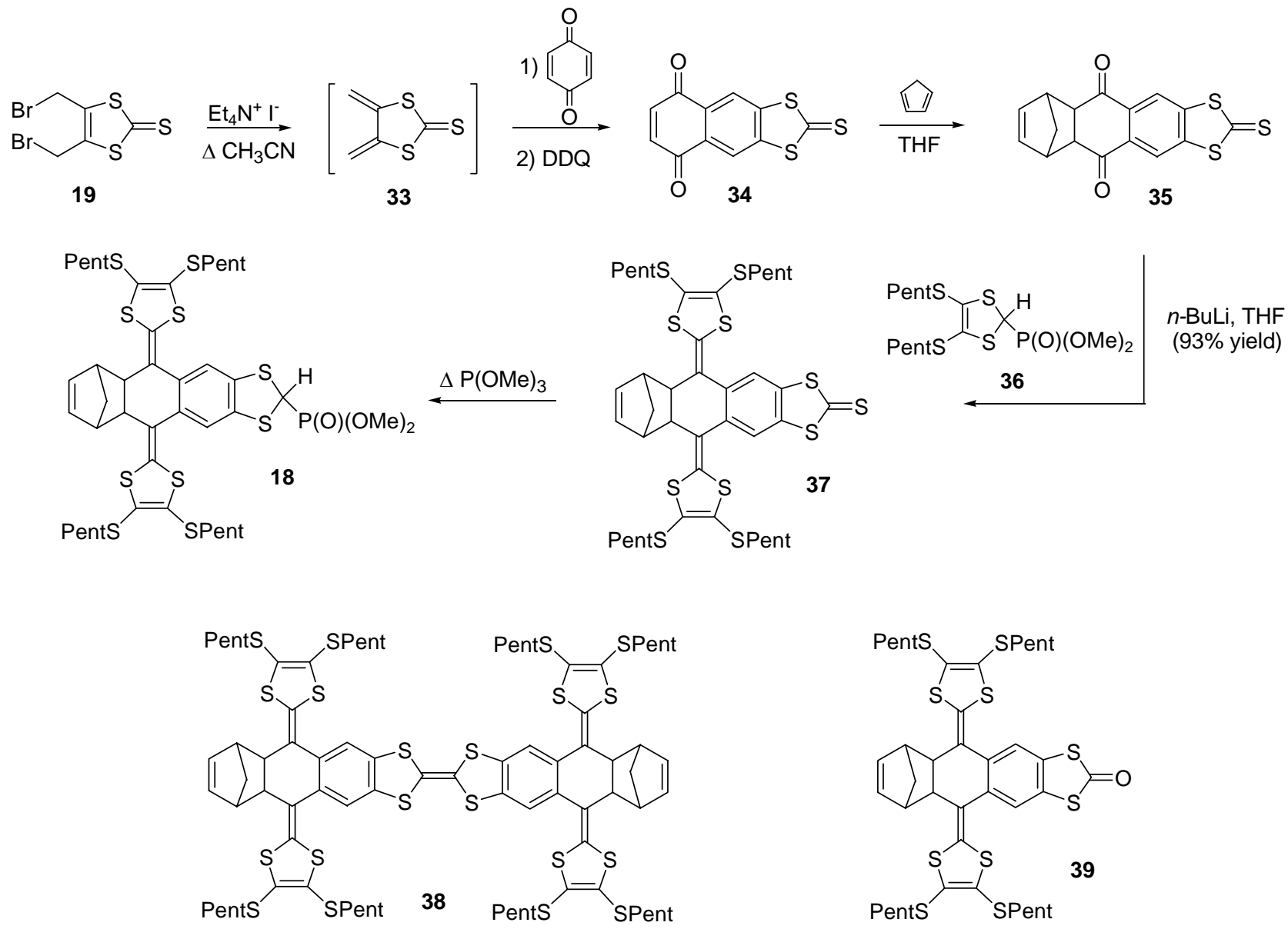

\section{Scheme 13}

This phosphonate 18 allows to prepare novel extended TTF-based donors with increased dimensionality and prone to undergo multistep redox systems. In particular, we developed the HWE reaction to reach highly extended architectures presenting the $\mathrm{C}_{2}$ or $\mathrm{C}_{3}$ symmetry, using the suitable polyformylated aromatic spacer. Thus, the reaction of the phosphonate anion generated from 18 with terephthaldehyde gave a mixture of both mono-olefinated and bisolefinated 40 and 41 compounds respectively (Scheme 14). These products were separated by chromatography on silica gel and compound $\mathbf{4 1}$ was isolated as orange crystals in $51 \%$ yield. The structure of $\mathbf{4 1}$ was confirmed by spectroscopic data and it should be noted that the mass spectrum presents the molecular peak as well as fragment peaks resulting from the successive retroDiels-Alder reactions eliminating cyclopentadiene molecules. We took advantage of this 
peculiarity to carry out the thermal deprotection of quinonic double bonds. The conversion into extended-TTF 42 was performed efficiently by refluxing an $o$-dichlorobenzene solution of product 41.

Table 1. Influence of experimental parameters for the transformation of 2-(thi)oxo-1,3-dithiole 37 or 39 with trimethylphosphite

\begin{tabular}{|c|c|c|c|c|c|c|}
\hline $\begin{array}{c}\text { Starting } \\
\text { material }\end{array}$ & $\begin{array}{c}\text { Concentration } \\
\text { of } \mathbf{3 7} \text { or 39 } \\
\text { in } \mathrm{P}(\mathrm{OMe})_{3}\end{array}$ & Time $(\mathrm{h})$ & $\begin{array}{c}\text { Reaction } \\
\text { temperature } \\
\left({ }^{\circ} \mathrm{C}\right)\end{array}$ & $\begin{array}{c}\text { Yield of } \\
\text { phosphonate } \\
\mathbf{1 8}(\%)\end{array}$ & $\begin{array}{c}\text { Yield of } \\
\text { TTF 38 }(\%)\end{array}$ & $\begin{array}{c}\text { Yield of } \\
\mathbf{3 9}(\mathbf{\%})\end{array}$ \\
\hline $\mathbf{3 7}$ & $0.04 \mathrm{M}$ & 3 & 90 & 28 & 0 & 34 \\
\hline $\mathbf{3 7}$ & $0.04 \mathrm{M}$ & 4 & 140 & 31 & 9 & 14 \\
\hline $\mathbf{3 7}$ & $0.11 \mathrm{M}$ & 1 & 140 & 35 & 21 & 4 \\
\hline $\mathbf{3 7}$ & $0.22 \mathrm{M}$ & 1.5 & 140 & 28 & 21 & 0 \\
\hline $\mathbf{3 9}$ & $0.037 \mathrm{M}$ & 24 & 140 & 41 & traces & 0 \\
\hline $\mathbf{3 9}$ & $0.11 \mathrm{M}$ & 24 & 140 & 33 & 2 & 0 \\
\hline
\end{tabular}
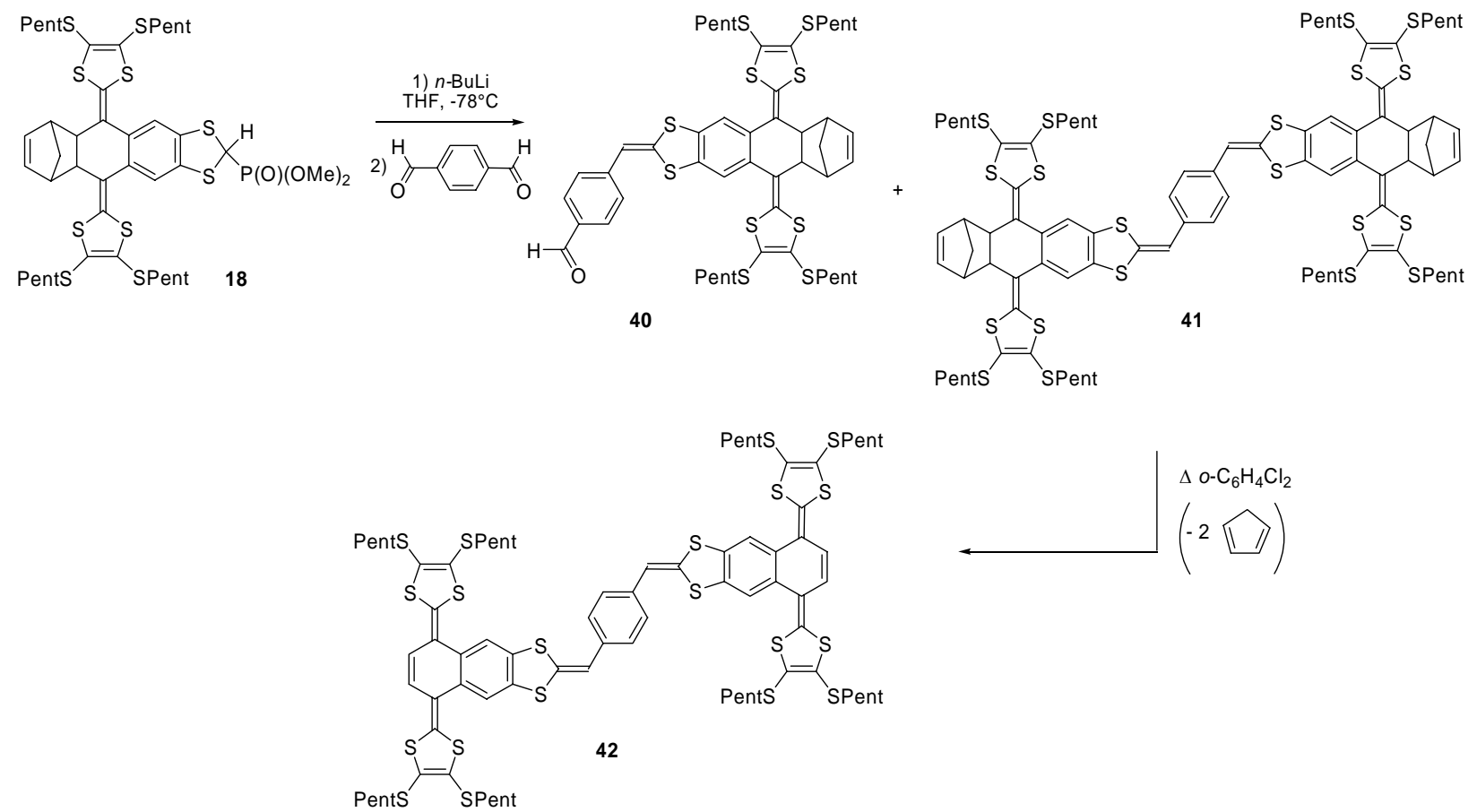

\section{Scheme 14}

The synthesis of TTF-based molecules with three-fold symmetry was previously investigated involving a Wittig reaction of both 1,3,5tris((triphenylphosphonium)methyl)benzene tribromide and monoformyl-TTF $1 .{ }^{25}$ In our case, we have considered the reverse strategy by achievement of the HWE reaction using phosphonate 
18 and 1,3,5-triformylbenzene ${ }^{25}$ as the electrophile. Following the procedure described for the synthesis of 41, the expected product 43 was isolated in $60 \%$ yield (Scheme 15). Retro DielsAlder was carried out by refluxing an $\boldsymbol{o}$-dichlorobenzene solution of $\mathbf{4 3}$ affording quantitatively the three-fold symmetry molecule 44 in which the benzene core is substituted in the 1,3,5positions by extended-TTF units.
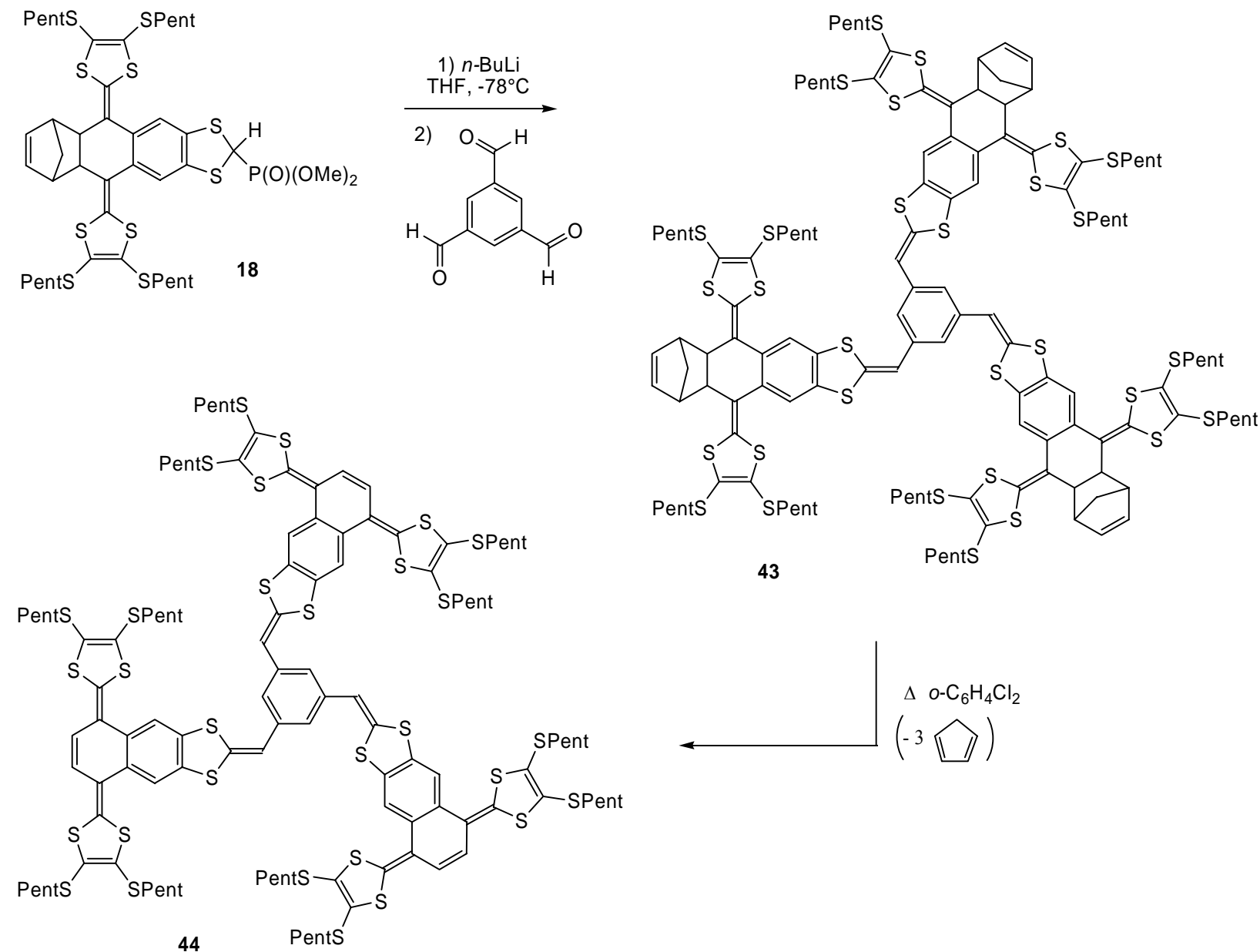

43

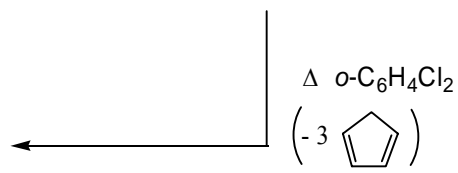

\section{Scheme 15}

\section{Conclusions}

In this work, two complementary approaches to build extended-TTF derivatives by polyolefinations are illustrated. On this basis, new powerful functionalized TTF synthons have been prepared, bearing either formyl or phosphonate groups. The Magtrieve ${ }^{\mathrm{TM}}$ reagent proved to constitute an appropriate smooth oxidant to allow the formation of (poly)formyl-TTF derivatives from the corresponding hydroxymethyl groups, without observation of TTF oxidation. Illustration of the wide applicability of these TTF synthons (poly(formyl) and 
poly(phosphonate)) is given by the construction of various original families of extended TTF derivatives. Work is now in progress to generate oxidized salts from these different families, in particular using the electrocrystallization technique. ${ }^{26}$

\section{Experimental Section}

General Procedures. Unless otherwise noted, chemicals were purchased from commercial suppliers and used without further purification. All solvents were distilled prior to use (THF and toluene from $\mathrm{Na}$ /benzophenone, $\mathrm{CH}_{2} \mathrm{Cl}_{2}$ from $\mathrm{P}_{2} \mathrm{O}_{5}, \mathrm{CH}_{3} \mathrm{CN}$ from $\mathrm{CaH}_{2}$ ). Column chromatography was performed on silica gel 60 from Merck (40-63 $\mu \mathrm{m})$.

Equipment. Kugelrohr distillation was performed using a Büchi B-580 apparatus. Melting points were determined using a microscope $\mathrm{RCH}(\mathrm{C}$. Reichert) with a Kofler hot stage and are uncorrected. ${ }^{1} \mathrm{H}$ and ${ }^{13} \mathrm{C}$ NMR spectra were recorded on a Brucker AC 200 (200 MHz), Brucker ACX 400 (400 MHz) or Brucker Avance DRX 500 (500 MHz) spectrometer and chemical shifts are reported in ppm using TMS as an internal standard. Infrared spectra were recorded on a FTIR Brucker Vector 22 spectrometer. Mass spectra were recorded on a VG Autospec spectrometer (Zaragoza) and on Kratos Kompact MALDI 2 spectrometer (Barcelona). X-ray diffraction : Data collection was carried out on an Enraf-Nonius CAD4 diffractometer. Elemental microanalyses were performed by the Central Service of Microanalysis of the CNRS (Vernaison, France).

\section{Compound characterization}

\section{2-Formyl-tetrathiafulvalene (1) was prepared according to ref. 8.}

2-Formyl-6,7-bis(pentylsulfanyl)tetrathiafulvalene (2). A solution of 2-(hydroxymethyl)TTF 9 (204 mg; $0.46 \mathrm{mmol})$ and a large excess of Magtrieve ${ }^{\mathrm{TM}}(716 \mathrm{mg})$ in $\mathrm{CH}_{2} \mathrm{Cl}_{2}(2.5 \mathrm{~mL})$ was refluxed for $1 \mathrm{~h} 30$. After cooling and dilution with $\mathrm{CH}_{2} \mathrm{Cl}_{2}$, the solution was filtered. The solvent was removed in vacuo and the residue was purified by chromatography on silica gel using $\mathrm{CH}_{2} \mathrm{Cl}_{2} /$ petroleum ether (1/1) as the mixture of eluents affording a red oil which crystallized by standing in the freezer giving red crystals $\left(130 \mathrm{mg} ; 65 \%\right.$ yield). M.p. $=44^{\circ} \mathrm{C}$ $\left(\mathrm{CH}_{2} \mathrm{Cl}_{2} /\right.$ petroleum ether). ${ }^{l} \mathrm{H} N M R\left(C D C l_{3}\right) \delta: 0.90\left(\mathrm{t}, 6 \mathrm{H}, \mathrm{CH}_{2} \mathrm{C}_{3},{ }^{3} \mathrm{~J}=7 \mathrm{~Hz}\right), 1.25-1.45(\mathrm{~m}$, $8 \mathrm{H}, \underline{\mathrm{C}}_{2} \mathrm{C}_{2} \mathrm{CH}_{3}$ ), 1.63 (qu, 4H, $\mathrm{SCH}_{2} \mathrm{CH}_{2},{ }^{3} \mathrm{~J}=7 \mathrm{~Hz}$ ), 2.80 and $2.81\left(2 \mathrm{t}, 4 \mathrm{H}, \mathrm{CH}_{2} \mathrm{~S},{ }^{3} \mathrm{~J}=7 \mathrm{~Hz}\right.$ ), $7.44(\mathrm{~s}, 1 \mathrm{H},=\mathrm{CH}), 9.47(\mathrm{~s}, 1 \mathrm{H}, \mathrm{CHO}) .{ }^{13} \mathrm{C} \mathrm{NMR}\left(\mathrm{CDCl}_{3}\right) \delta: 14.6\left(\mathrm{CH}_{2} \mathrm{CH}_{3}\right), 22.8\left(\mathrm{C}_{2} \mathrm{CH}_{3}\right)$, $30.0\left(\mathrm{SCH}_{2} \mathrm{CH}_{2}\right), 31.2\left(\underline{\mathrm{CH}}_{2} \mathrm{CH}_{2} \mathrm{CH}_{3}\right), 37.0\left(\mathrm{SCH}_{2}\right), 110.2$ and 111.6 (cent. $\left.\mathrm{C}=\mathrm{C}\right), 127.7$ and $129.3(\mathrm{~S} \underline{\mathrm{C}}=\underline{\mathrm{CS}}), 140.2(\mathrm{C}=\underline{\mathrm{C}}-\mathrm{H}), 141.9(=\underline{\mathrm{C}}-\mathrm{CHO}), 180.2(\mathrm{C}=\mathrm{O}) . M S$ EI m/e (I\%) : $436\left(\mathrm{M}^{+}\right.$, 100), 364 (21), 331 (39), 294 (36), 174 (31).

6,7-Bis(ethylenedisulfanyl)-2,3-bis(formyl)TTF (3). Method A. A solution of acetal TTF derivative 12 (212 $\mathrm{mg} ; 0.50 \mathrm{mmol})$ in $\mathrm{CH}_{2} \mathrm{Cl}_{2}(20 \mathrm{~mL})$ was treated with formic acid $(99 \%)(5$ $\mathrm{mL}$ ). The initial red solution turned immediately to deep blue. After $30 \mathrm{~min}$ of stirring, $\mathrm{CH}_{2} \mathrm{Cl}_{2}$ and $\mathrm{Na}_{2} \mathrm{CO}_{3}$ were successively added. The resulting organic layer was washed with water, dried 
over $\mathrm{MgSO}_{4}$ and the solvent was removed in vacuo. Blue needles of 3 were collected from recrystallization in toluene (122 $\mathrm{mg} ; 70 \%$ yield).

Method B. To a solution of diol $\mathbf{1 4}^{14}(200 \mathrm{mg} ; 0.56 \mathrm{mmol})$ in a THF $(20 \mathrm{~mL}) / \mathrm{CH}_{2} \mathrm{Cl}_{2}(20 \mathrm{~mL})$ mixture at room temperature, was added Magtrieve ${ }^{\mathrm{TM}}(1.5 \mathrm{~g})$. The reaction mixture was refluxed overnight, and the oxidizing agent was discarded by filtration. The filtrate was evaporated and purified by column chromatography using $\mathrm{CH}_{2} \mathrm{Cl}_{2}$ /petroleum ether (7/3) as the mixture of eluents to afford dialdehyde 3 as deep blue needles $(101 \mathrm{mg} ; 50 \%)$. M.p. $=210-211^{\circ} \mathrm{C}$ (toluene). ${ }^{l} \mathrm{H}$ $N M R\left(\mathrm{CDCl}_{3}\right) \delta: 3.30\left(\mathrm{~s}, 4 \mathrm{H}, \mathrm{CH}_{2}\right), 10.21(\mathrm{~s}, 2 \mathrm{H}, \mathrm{CHO}) . I R(\mathrm{KBr}): 1650$ and $1690 \mathrm{~cm}^{-1}(\mathrm{C}=\mathrm{O})$. MS m/e (I\%) : $350\left(\mathrm{M}^{+}, 100\right)$. Elemental analysis for $\mathrm{C}_{10} \mathrm{H}_{6} \mathrm{O}_{2} \mathrm{~S}_{6}(349.87)$ calcd. C $34.26 \mathrm{H} 1.73$ O 9.13; found C $34.08 \mathrm{H} 1.58$ O 9.30.

2,3,6,7-Tetraformyl-TTF (4) was prepared according to ref.13.

2,3-Dimethoxycarbonyl-6,7-bis(pentylsulfanyl)tetrathiafulvalene (7). A solution of 2-oxo1,3-dithiole 6 (4.68 g; $20 \mathrm{mmol})$ and 2-thioxo-1,3-dithiole 5 (6.76 g; $20 \mathrm{mmol})$ in trimethylphosphite $(200 \mathrm{~mL})$ was heated at $80^{\circ} \mathrm{C}$ for $4 \mathrm{~h}$. Trimethylphosphite was removed in vacuo and the residue was purified by chromatography on silica gel using $\mathrm{CH}_{2} \mathrm{Cl}_{2}$ /petroleum ether $(1 / 4)$ as the mixture of eluents to remove 2,3,6,7-tetrakis(pentylsulfanyl)TTF. Further elution using $\mathrm{CH}_{2} \mathrm{Cl}_{2}$ /petroleum ether (7/3) as the mixture of eluents afforded $6.50 \mathrm{~g}$ ( $62 \%$ yield) of dissymmetrical TTF as a purple oil. ${ }^{1} H \mathrm{NMR}\left(\mathrm{CDCl}_{3}\right) \delta: 0.89\left(\mathrm{t}, 6 \mathrm{H}, \mathrm{CH}_{3}-\mathrm{CH}_{2},{ }^{3} \mathrm{~J}=7 \mathrm{~Hz}\right)$, 1.30-1.40 (m, 8H, $\left.\mathrm{CH}_{3}-\underline{\mathrm{C}}_{2}-\mathrm{C}_{2}\right), 1.55-1.65$ (m, 4H, $\left.\underline{\mathrm{C}}_{2}-\mathrm{CH}_{2} \mathrm{~S}\right), 2.80\left(\mathrm{t}, 4 \mathrm{H}, \mathrm{CH}_{2} \mathrm{~S},{ }^{3} \mathrm{~J}=7 \mathrm{~Hz}\right)$, $3.83\left(\mathrm{~s}, 6 \mathrm{H}, \mathrm{CH}_{3} \mathrm{O}\right)$.

2-Methoxycarbonyl-6,7-bis(pentylsulfanyl)tetrathiafulvalene (8). A solution of TTF diester 7 (3.00 g; $5.72 \mathrm{mmol}), \mathrm{LiBr}(8.93 \mathrm{~g} ; 102.9 \mathrm{mmol})$ in DMF $(60 \mathrm{~mL})$ was heated for $2 \mathrm{~h}$ at $120^{\circ} \mathrm{C}$. The reaction mixture was cooled, then brine $(10 \mathrm{~mL})$ and EtOAc $(250 \mathrm{~mL})$ were added. The organic layer was washed with brine $(3 \times 100 \mathrm{~mL})$, dried $\left(\mathrm{MgSO}_{4}\right)$ and the solvent was removed in vacuo. The residue was purified by chromatography on silica gel using $\mathrm{CH}_{2} \mathrm{Cl}_{2}$ as the eluent

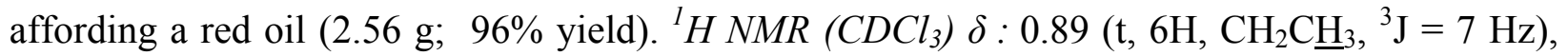
1.20-1.50 (m, 8H, $\left.\underline{\mathrm{CH}}_{2} \mathrm{CH}_{2} \mathrm{CH}_{3}\right), 1.63$ (qu, 4H, $\left.\mathrm{SCH}_{2} \mathrm{CH}_{2},{ }^{3} \mathrm{~J}=7 \mathrm{~Hz}\right), 2.80$ and $2.81(2 \mathrm{t}, 4 \mathrm{H}$, $\left.\mathrm{CH}_{2} \mathrm{~S},{ }^{3} \mathrm{~J}=7 \mathrm{~Hz}\right), 3.81\left(\mathrm{~s}, 3 \mathrm{H}, \mathrm{OCH}_{3}\right), 7.34(\mathrm{~s}, 1 \mathrm{H}, \mathrm{CH}) .{ }^{13} \mathrm{C} \mathrm{NMR}\left(\mathrm{CDCl}_{3}\right) \delta: 14.6\left(\mathrm{CH}_{2} \mathrm{CH}_{3}\right)$, $22.8\left(\underline{\mathrm{CH}}_{2} \mathrm{CH}_{3}\right), 31.3\left(\mathrm{SCH}_{2} \underline{\mathrm{CH}}_{2}\right), 30.1\left(\underline{\mathrm{CH}}_{2} \mathrm{CH}_{2} \mathrm{CH}_{3}\right), 37.0\left(\mathrm{SCH}_{2}\right), 53.4\left(\mathrm{CH}_{3} \mathrm{O}\right), 110.7$ and 111.6 (cent. $\mathrm{C}=\mathrm{C}), 128.0\left(=\underline{\mathrm{C}}-\mathrm{CO}_{2} \mathrm{Me}\right), 128.8$ and $129.0(\mathrm{~S} \underline{\mathrm{C}}=\underline{\mathrm{CS}}), 132.6(\mathrm{C}=\underline{\mathrm{C}}-\mathrm{H}), 160.4(\mathrm{C}=\mathrm{O})$. MS EI m/e (I\%) : 466 (M+, 100), 394 (14), 361 (30), 324 (22), 204 (21).

2-Hydroxymethyl-6,7-bis(pentylsulfanyl)tetrathiafulvalene (9). To a solution of TTF monoester 8 in dry $\mathrm{CH}_{2} \mathrm{Cl}_{2}(50 \mathrm{~mL})(1.16 \mathrm{~g} ; 2.49 \mathrm{mmol})$ was slowly added at $-78^{\circ} \mathrm{C}$ under nitrogen DiBAl-H 1M solution in hexane $(14.9 \mathrm{~mL} ; 14.9 \mathrm{mmol})$. After stirring for $45 \mathrm{~min}$ at $78^{\circ} \mathrm{C}$, the reaction mixture was hydrolysed using a solution of $\mathrm{HCl} 6 \mathrm{M} / \mathrm{MeOH}(1 / 1)(2 \mathrm{~mL})$. After dilution with $\mathrm{CH}_{2} \mathrm{Cl}_{2}(30 \mathrm{~mL})$, the organic layer was extracted, then washed with an aqueous $\mathrm{HCl} 1 \mathrm{M}$ solution $(30 \mathrm{~mL})$, brine $(3 \times 50 \mathrm{~mL})$ and dried $\left(\mathrm{MgSO}_{4}\right)$. The solvent was removed in vacuo and the residue was purified by chromatography on silica gel using $\mathrm{CH}_{2} \mathrm{Cl}_{2}$ as the eluent affording orange crystals of 2-(hydroxymethyl)TTF $(1.00 \mathrm{~g} ; 92 \%$ yield). M.p. $=31$ $32^{\circ} \mathrm{C}\left(\mathrm{CH}_{2} \mathrm{Cl}_{2}\right) .{ }^{1} \mathrm{H} N M R\left(\mathrm{CDCl}_{3}\right) \delta: 0.90\left(\mathrm{t}, 6 \mathrm{H}, \mathrm{CH}_{2} \mathrm{CH}_{3},{ }^{3} \mathrm{~J}=7 \mathrm{~Hz}\right), 1.20-1.50(\mathrm{~m}, 8 \mathrm{H}$, 
$\mathrm{C}_{2} \mathrm{CH}_{2} \mathrm{CH}_{3}$ ), 1.63 (qu, 4H, $\mathrm{SCH}_{2} \underline{\mathrm{CH}}_{2},{ }^{3} \mathrm{~J}=7 \mathrm{~Hz}$ ), 2.03 (br.s., $1 \mathrm{H}, \mathrm{OH}$ ), 2.81 (t, 4H, $\mathrm{CH}_{2} \mathrm{~S},{ }^{3} \mathrm{~J}=$ $7 \mathrm{~Hz}), 4.39$ (s, 2H, $\left.\underline{\mathrm{CH}}_{2} \mathrm{OH}\right), 6.22$ (s, 1H, CH). MS EI m/e (I\%) : 438 (M $\left.\mathrm{M}^{+}, 100\right), 366$ (20), 333 (31), 296 (23), 176 (27).

6,7-Bis(ethylenedisulfanyl)-2-formyl-3-diethylacetal tetrathiafulvalene (12). To a freshly distilled (over $\left.\mathrm{CaH}_{2}\right)$ toluene solution of thiones $10(10 \mathrm{mmol})$ and $11(30 \mathrm{mmol})$, was slowly added $\mathrm{Co}_{2}(\mathrm{CO})_{8}$ under nitrogen. The mixture was refluxed for $5 \mathrm{~h}$. After cooling to room temperature, the solution was filtered over a short silica gel column $\left(\mathrm{CH}_{2} \mathrm{Cl}_{2}\right)$. The solvent was removed in vacuo and the residue corresponding to a mixture of symmetrical coupling products and the desired dissymmetrical one, was purified by column chromatography on silica gel $\left(\mathrm{CH}_{2} \mathrm{Cl}_{2}\right.$ then $\left.\mathrm{CH}_{2} \mathrm{Cl}_{2} / \mathrm{Et}_{2} \mathrm{O} ; 9 / 1\right)$ to afford 12 as a red solid $\left(13 \%\right.$ yield). M.p. $=73-77^{\circ} \mathrm{C}$. ${ }^{1} \mathrm{H} N M R$ $\left(\mathrm{CDCl}_{3}\right) \delta: 1.24\left(\mathrm{t}, 6 \mathrm{H}, \mathrm{CH}_{3}\right), 3.29\left(\mathrm{~s}, 4 \mathrm{H}, \mathrm{CH}_{2} \mathrm{~S}\right), 3.65\left(\mathrm{~m}, 4 \mathrm{H}, \mathrm{OCH}_{2}\right), 5.73(\mathrm{~s}, 1 \mathrm{H}, \mathrm{CH}), 9.86$ (s, 1H, CHO). IR (KBr) cm $\mathrm{cm}^{-1} 1652(\mathrm{C}=\mathrm{O}) . M S(F A B)$ calcd for $\mathrm{C}_{14} \mathrm{H}_{16} \mathrm{O}_{3} \mathrm{~S}_{8}$ : 424.125; found : $424.321\left(\mathrm{M}^{+}\right)$.

4,5-Bis(dimethylphosphono)methyl-2-thioxo-1,3-dithiole (15). A solution of 4,5bis(bromomethyl)-2-thioxo-1,3-dithiole $\mathbf{1 9}^{14}$ (1 g; $\left.3.12 \mathrm{mmol}\right)$ in trimethylphosphite $(10 \mathrm{~mL})$ was heated for $2 \mathrm{~h}$ at $100^{\circ} \mathrm{C}$. The excess of trimethylphosphite was removed in vacuo then dimethyl methylphosphonate was eliminated by distillation under reduced pressure using a Kugelrohr apparatus. The residue was purified by chromatography on silica gel using EtOAc/MeOH (4/1) as the eluent. Recrystallization in $\mathrm{CH}_{2} \mathrm{Cl}_{2} /$ petroleum ether afforded $540 \mathrm{mg}$ of orange crystals $\left(46 \%\right.$ yield). M.p. $=105-107^{\circ} \mathrm{C} .{ }^{1} H N M R\left(C D C l_{3}\right) \delta: 3.23\left(\mathrm{~d}, 4 \mathrm{H}, \mathrm{CH}_{2},{ }^{2} \mathrm{~J}_{\mathrm{H}-\mathrm{P}}=\right.$ $18.3 \mathrm{~Hz}), 3,75\left(\mathrm{~d}, 12 \mathrm{H}, \mathrm{CH}_{3},{ }^{3} \mathrm{~J}_{\mathrm{H}-\mathrm{P}}=10.8 \mathrm{~Hz}\right) .{ }^{13} \mathrm{CNMR}\left(\mathrm{CDCl}_{3}\right) \delta: 26.4$ and $26.5\left(2 \mathrm{~d}, \mathrm{CH}_{2},{ }^{1} \mathrm{~J}_{\mathrm{C}-\mathrm{P}}\right.$ $=145 \mathrm{~Hz}), 53.9$ and $54.0\left(2 \mathrm{~d}, \mathrm{CH}_{3},{ }^{2} \mathrm{~J}_{\mathrm{C}-\mathrm{P}}=4.4 \mathrm{~Hz}\right), 132.2(\mathrm{C}=\mathrm{C}), 210.8(\mathrm{C}=\mathrm{S}) . I R(\mathrm{KBr}) \mathrm{cm}^{-}$ ${ }^{l}: 1250(\mathrm{P}=\mathrm{O}), 1051(\mathrm{C}=\mathrm{S}), 1028(\mathrm{P}-\mathrm{O}-\mathrm{C}) . M S$ EI m/e (I\%): 377 ((M-H) $\left.{ }^{+}, 60\right), 301(82), 269$ (44), 193 (100).

2,3-Bis(dimethylphosphono)methyl-6,7-dimethylsulfanyltetrathiafulvalene (16). A solution of 2,3-bis(bromomethyl)TTF $\mathbf{2 0}^{21}$ (200 mg; $0.41 \mathrm{mmol}$ ) in trimethylphosphite $(10 \mathrm{~mL})$ was heated for $1 \mathrm{~h} 30$ at $140^{\circ} \mathrm{C}$. After evaporation of the excess trimethylphosphite and elimination of dimethyl methylphosphonate by distillation using the Kugelrohr apparatus $\left(60^{\circ} \mathrm{C}, 9 \mathrm{~mm} \mathrm{Hg}\right)$, the residue was purified by chromatography on silica gel using EtOAc/ $\mathrm{MeOH}(9 / 1)$ as the mixture of eluents. Recrystallization in $\mathrm{CH}_{2} \mathrm{Cl}_{2} / \mathrm{MeOH}$ afforded $90 \mathrm{mg}$ of brown crystals (40\% yield). M.p $=138-140^{\circ} \mathrm{C} .{ }^{1} \mathrm{H} \mathrm{NMR}\left(\mathrm{CDCl}_{3}\right) \delta: 2.41\left(\mathrm{~s}, 6 \mathrm{H}, \mathrm{CH}_{3} \mathrm{~S}\right), 3.05\left(\mathrm{~d}, 4 \mathrm{H}, \mathrm{CH}_{2} \mathrm{P},{ }^{2} \mathrm{~J}_{\mathrm{H}-\mathrm{P}}=17.8 \mathrm{~Hz}\right)$, $3.78\left(\mathrm{~d}, 12 \mathrm{H}, \mathrm{CH}_{3} \mathrm{O},{ }^{3} \mathrm{~J}=10.9 \mathrm{~Hz}\right) .{ }^{31} \mathrm{P} \mathrm{NMR}\left(\mathrm{CDCl}_{3}\right) \delta: 25.57 .{ }^{13} \mathrm{C} \mathrm{NMR}\left(\mathrm{CDCl}_{3}\right) \delta: 19.1$ $\left(\mathrm{CH}_{3} \mathrm{~S}\right), 26.0\left(\mathrm{~d}, \mathrm{CH}_{2} \mathrm{P},{ }^{1} \mathrm{~J}_{\mathrm{C}-\mathrm{P}}=146 \mathrm{~Hz}\right), 53.2\left(\mathrm{CH}_{3} \mathrm{O}\right), 107.0$ and 112.3 (cent. $\left.\mathrm{C}=\mathrm{C}\right), 120.8(\underline{\mathrm{C}}=\underline{\mathrm{C}}-$ $\left.\mathrm{CH}_{2}\right), 127.5\left(\mathrm{~S}_{2} \underline{\mathrm{C}}=\underline{\mathrm{CS}}_{2}\right) . I R(\mathrm{KBr}) \mathrm{cm}^{-1}: 1253(\mathrm{P}=\mathrm{O}), 1029(\mathrm{P}-\mathrm{O}-\mathrm{C}) . M S E I m / e(I \%): 540\left(\mathrm{M}^{+}\right.$, 45), 525 (9), 390 (12), 91 (66), 45 (100). Elemental analysis for $\mathrm{C}_{14} \mathrm{H}_{22} \mathrm{O}_{6} \mathrm{~S}_{6} \mathrm{P}_{2}$ (539.92) calcd. C $31.10 \mathrm{H} 4.10 \mathrm{~S} 35.58 \mathrm{P} 11.46$; found C $30.75 \mathrm{H} 3.88 \mathrm{~S} 34.10 \mathrm{P} 11.12$.

Compound (22). To a solution of 2-thioxo-1,3-dithiole 15 (500 mg; $1.32 \mathrm{mmol})$ in $\mathrm{CH}_{2} \mathrm{Cl}_{2}$ (15 $\mathrm{mL})$ were added methyl trifluoromethanesulfonate $(152 \mu \mathrm{L} ; 1.38 \mathrm{mmol})$. After stirring for $3 \mathrm{~h}$ at room temperature, the solvent was removed in vacuo. The residue was dissolved in $\mathrm{CH}_{3} \mathrm{CN}$ (5 $\mathrm{mL}$ ) and propan-2-ol $(0.7 \mathrm{~mL})$, then sodium borohydride $(52 \mathrm{mg} ; 1.39 \mathrm{mmol})$ was added and 
stirring was pursued for $15 \mathrm{~min}$. After concentration, the residue was diluted with EtOAc and washed with brine. The organic layer was dried $\left(\mathrm{MgSO}_{4}\right)$ and concentrated. The residue was purified by chromatography on silica gel using EtOAc/MeOH (4/1) as the mixture of eluents affording $484 \mathrm{mg}$ of colourless oil (93\% yield). ${ }^{1} \mathrm{H} \mathrm{NMR}\left(\mathrm{CDCl}_{3}\right) \delta: 2.26\left(\mathrm{~s}, 3 \mathrm{H}, \mathrm{CH}_{3} \mathrm{~S}\right), 3.04$ and $3.06\left(2 \mathrm{~d}, 4 \mathrm{H}, \mathrm{CH}_{2},{ }^{2} \mathrm{~J}_{\mathrm{H}-\mathrm{P}}=18 \mathrm{~Hz}\right), 3.78$ and $3.80\left(2 \mathrm{~d}, 12 \mathrm{H}, \mathrm{CH}_{3} \mathrm{O},{ }^{3} \mathrm{~J}_{\mathrm{H}-\mathrm{P}}=7.3 \mathrm{~Hz}\right), 5.83(\mathrm{~s}$, $\left.3 \mathrm{H}, \mathrm{CH}_{3} \mathrm{~S}\right) .{ }^{13} \mathrm{C} N M R\left(\mathrm{CDCl}_{3}\right) \delta: 12.1\left(\mathrm{CH}_{3} \mathrm{~S}\right), 27.43$ and $27.5\left(2 \mathrm{~d}, \mathrm{CH}_{2},{ }^{1} \mathrm{~J}_{\mathrm{C}-\mathrm{P}}=145 \mathrm{~Hz}\right), 53.3$ $\left(2 \mathrm{~d}, \mathrm{CH}_{3} \mathrm{O},{ }^{2} \mathrm{~J}_{\mathrm{C}-\mathrm{P}}=3 \mathrm{~Hz}\right), 58.0(\mathrm{CH}), 117.9(\mathrm{C}=\mathrm{C}) . I R(\mathrm{KBr}) \mathrm{cm}^{-1}: 1265(\mathrm{P}=\mathrm{O}), 1034(\mathrm{P}-\mathrm{O}-\mathrm{C})$. MS EI m/e (I\%): $394\left(\mathrm{M}^{+}, 1\right), 346$ (100), 221 (33).

Tetrakis(dimethylphosphono)methyltetrathiafulvalene (17). To a solution of compound 22 $(336 \mathrm{mg} ; 0.85 \mathrm{mmol})$ in acetic anhydride $(2 \mathrm{~mL})$ was added at $0{ }^{\circ} \mathrm{C}_{\mathrm{HBF}} \cdot \mathrm{Et}_{2} \mathrm{O} 54 \%(0.23 \mathrm{~mL}$; $0.93 \mathrm{mmol})$. The reaction mixture was stirred for $4 \mathrm{~h}$ at room temperature. After addition of dry $\mathrm{Et}_{2} \mathrm{O}(40 \mathrm{~mL})$, the dithiolium salt was crystallized overnight at $-18^{\circ} \mathrm{C}$. The precipitate was filtered. After dissolution in $\mathrm{CH}_{3} \mathrm{CN}(3 \mathrm{~mL})$, triethylamine $(1.3 \mathrm{~mL})$ was added. After stirring for $15 \mathrm{~min}$, the reaction mixture was diluted with $\mathrm{CH}_{2} \mathrm{Cl}_{2}$, washed with brine and the organic layer was dried and concentrated to afford $230 \mathrm{mg}$ of colourless oil (81\% yield). ${ }^{1} \mathrm{H} \mathrm{NMR}\left(\mathrm{CDCl}_{3}\right)$ $\delta: 3.03\left(\mathrm{~d}, 8 \mathrm{H}, \mathrm{CH}_{2},{ }^{2} \mathrm{~J}_{\mathrm{H}-\mathrm{P}}=18 \mathrm{~Hz}\right), 3.75\left(\mathrm{~d}, 48 \mathrm{H}, \mathrm{CH}_{3},{ }^{3} \mathrm{~J}_{\mathrm{H}-\mathrm{P}}=10 \mathrm{~Hz}\right) .{ }^{13} \mathrm{C} \mathrm{NMR}\left(\mathrm{CDCl}_{3}\right)$ $\delta: 26.7\left(\mathrm{~d}, \mathrm{CH}_{2},{ }^{2} \mathrm{~J}_{\mathrm{C}-\mathrm{P}}=140 \mathrm{~Hz}\right), 53.7\left(\mathrm{CH}_{3}\right), 108.4$ (cent. $\left.\mathrm{C}=\mathrm{C}\right), 121.5(\mathrm{C}=\mathrm{C}) . M S E I m / e$ $(I \%): 692\left(\mathrm{M}^{+}, 6\right), 110(100)$.

p- $N, N$-Dimethylamino styrenyl tetrathiafulvalene (25). A solution of phosphonium salt 24 (209 mg; $0.40 \mathrm{mmol})$ in dry THF $(10 \mathrm{~mL})$ was cooled to $0^{\circ} \mathrm{C}$ under nitrogen. $t$-BuOK $(56 \mathrm{mg}$, $0.50 \mathrm{mmol}$ ) was added in one portion, and the resulting red solution was stirred for $15 \mathrm{~min}$ before adding a solution of formyl-TTF 1 (46 mg; $0.2 \mathrm{mmol})$ in dry THF $(5 \mathrm{~mL})$. The mixture was stirred overnight at room temperature, and the solvent was removed in vacuo. After addition of $\mathrm{CH}_{2} \mathrm{Cl}_{2}$, the organic layer was washed twice with water, and dried over $\mathrm{MgSO}_{4}$. The solvent was concentrated and the residue was purified by chromatography on silica gel using $\mathrm{CH}_{2} \mathrm{Cl}_{2}$ /petroleum ether $(10 / 1)$ as the mixture of eluents. Compound $\mathbf{2 5}$ was obtained as small orange pellets $\left(82 \%\right.$ yield). M.p. $=205-208^{\circ} \mathrm{C}\left(\mathrm{CH}_{2} \mathrm{Cl}_{2}\right) .{ }^{1} \mathrm{H} \mathrm{NMR}\left(\mathrm{CDCl}_{3}\right) \delta: 2.98(\mathrm{~s}, 6 \mathrm{H}$, $\left.\mathrm{NCH}_{3}\right), 6.22$ (s, 1H, SCH), 6.32 (s, 2H, SCH=CHS), 6.34 (d, 1H, TTFCH=CHAr, ${ }^{3} \mathrm{~J}=16 \mathrm{~Hz}$ ), $6.67\left(\mathrm{~d}, 2 \mathrm{H}, \mathrm{ArH},{ }^{3} \mathrm{~J}=9 \mathrm{~Hz}\right), 6.69\left(\mathrm{~d}, 1 \mathrm{H}, \mathrm{TTFCH}=\mathrm{CHAr},{ }^{3} \mathrm{~J}=16 \mathrm{~Hz}\right), 7.296 .67\left(\mathrm{~d}, 2 \mathrm{H}, \mathrm{ArH},{ }^{3} \mathrm{~J}\right.$ $=9 \mathrm{~Hz})$. (HRMS, FAB) m/e 349.006943; $\mathrm{C}_{16} \mathrm{H}_{15} \mathrm{NS}_{4}$ requires : 349.008737 .

2,3-Bis(p- $N, N$-dimethylamino styrenyl)-6,7-bis(ethylenedisulfanyl) tetrathiafulvalene (26). A solution of phosphonium salt $24(418 \mathrm{mg} ; 0.80 \mathrm{mmol})$ in dry THF $(20 \mathrm{~mL})$ was cooled to $0^{\circ} \mathrm{C}$ under nitrogen. $t$-BuOK (112 mg; $1.00 \mathrm{mmol})$ was added in one portion, and the resulting red solution was stirred for $15 \mathrm{~min}$ before the addition of a solution of diformyl-TTF 3 (70 $\mathrm{mg} ; 0.2$ $\mathrm{mmol})$ in THF $(10 \mathrm{~mL})$. The mixture was stirred at room temperature for $2 \mathrm{~h}$, and the solvent was evaporated. After addition of $\mathrm{CH}_{2} \mathrm{Cl}_{2}$, the organic phase was washed twice with water, and dried over $\mathrm{MgSO}_{4}$. The solvent was removed in vacuo and the residue was purified by chromatography on silica gel using $\mathrm{CH}_{2} \mathrm{Cl}_{2}$ /cyclohexane (5/1) as the mixture of eluents to give 26 as a red powder (75\% yield). One fraction was recrystallized by slow diffusion of $\mathrm{MeOH}$ in a $\mathrm{CH}_{2} \mathrm{Cl}_{2}$ solution of 26 affording orange needles. M.p. $=210-214^{\circ} \mathrm{C}\left(\mathrm{CH}_{2} \mathrm{Cl}_{2} / \mathrm{MeOH}\right) .{ }^{l} \mathrm{H} N M R$ 
$\left(\mathrm{CDCl}_{3}\right) \delta 3.01\left(\mathrm{~s}, 12 \mathrm{H}, \mathrm{NCH}_{3}\right), 3.30\left(\mathrm{~s}, 4 \mathrm{H}, \mathrm{SCH}_{2}\right), 6.48\left(\mathrm{~d}, 2 \mathrm{H}, \mathrm{TTFCH}=\mathrm{CHAr},{ }^{3} \mathrm{~J}=16 \mathrm{~Hz}\right)$, $6.70\left(\mathrm{~d}, 4 \mathrm{H}, \mathrm{ArH},{ }^{3} \mathrm{~J}=9 \mathrm{~Hz}\right), 7.05\left(\mathrm{~d}, 2 \mathrm{H}, \mathrm{TTFCH}=\mathrm{CHAr},{ }^{3} \mathrm{~J}=16 \mathrm{~Hz}\right), 7.36\left(\mathrm{~d}, 4 \mathrm{H}, \mathrm{ArH},{ }^{3} \mathrm{~J}=9\right.$ Hz). IR (KBr) cm $\mathrm{cm}^{-1}: 1590,1510,1350,1165$. (MS, FAB+) m/e (I\%): $584\left(\mathrm{M}^{+}, 55\right), 482(35), 460$ (35), 379 (35).

Crystallographic data : $\mathrm{C}_{28} \mathrm{~N}_{2} \mathrm{~S}_{6}, \mathrm{M}=556.70$, red needle, $0.60 \times 0.23 \times 0.20 \mathrm{~mm}^{3}$, monoclinic, space group $P 2{ }_{1} / m, \mathrm{a}=5.754(2) \AA, \mathrm{b}=25.392(9) \AA, \mathrm{c}=9.862(5) \AA, \beta=90.90(5)^{\circ}, \mathrm{V}=1441(1)$ $\AA^{3}, \mathrm{Z}=2$, pcalc $=1.280 \mathrm{~g} / \mathrm{cm}^{3}, \mu(\mathrm{MoK} \alpha)=0.493 \mathrm{~mm}^{-1}, \mathrm{~F}(000)=556, \theta \min =2.5^{\circ}, \theta \max =$ $29.98^{\circ}, 4606$ data unique, parameters $=166, \mathrm{R} 1=0.055$ and $\mathrm{wR} 2=0.063$ using 1687 reflections with $\mathrm{I}>3 \sigma(\mathrm{I}), \mathrm{R} 1=0.119$ and $\mathrm{wR} 2=0.101 \mathrm{using}$ all data, $\mathrm{GOF}=1.042,-0.177<\Delta \rho$ $<0.229$ e. $\AA^{-3}$. X-ray data were collected at $293 \mathrm{~K}$ on a Enraf Nonius Mach3 four circles diffractometer equipped with a graphite monochromator utilizing MoK $\alpha$ radiation $(\lambda=0.71073$ $\AA$ ). The structure was solved by direct methods (SIR) using MolEN package programs ${ }^{27}$ and refined on $\mathrm{F}$ by full matrix least-squares method with anisotropic thermal parameters for all non$\mathrm{H}$ atoms. Absorption was corrected by DIFABS. CCDC 292490 contains the supplementary crystallographic data for this paper.

Tetrakis(p-N,N-dimethylaminostyrenyl)TTF (27). A solution of phosphonium salt $\mathbf{2 4} \mathbf{2}^{22}$ (2.092 $\mathrm{g}$; $4 \mathrm{mmol})$ in dry THF $(30 \mathrm{~mL})$ was cooled to $0^{\circ} \mathrm{C}$ under nitrogen. $t$-BuOK (494 mg; $\left.4.40 \mathrm{mmol}\right)$ was added in one portion, and the resulting red solution was stirred for $15 \mathrm{~min}$ before the addition of a solution of tetraformyl-TTF $4(158 \mathrm{mg} ; 0.50 \mathrm{mmol})$ in dry THF $(30 \mathrm{~mL})$. The mixture was stirred overnight at room temperature. The reaction mixture was poured onto a magnetically stirred $\mathrm{MeOH}$ solution $(200 \mathrm{~mL})$. Stirring was pursued for two additionnal hours. The precipitate obtained was filtered through a frit-glass $\left(\mathrm{N}^{\circ} 4\right)$ to afford a red-violet microcrystalline powder $\left(312 \mathrm{mg} ; 80 \%\right.$ yield). M.p. $=266-268^{\circ} \mathrm{C}(\mathrm{MeOH}) .{ }^{1} \mathrm{HNMR}\left(C D C l_{3}\right) \delta$ $3.01\left(\mathrm{~s}, 24 \mathrm{H}, \mathrm{NCH}_{3}\right), 6.53\left(\mathrm{~d}, 4 \mathrm{H}, \mathrm{TTFCH}=\mathrm{CHAr},{ }^{3} \mathrm{~J}=16 \mathrm{~Hz}\right), 6.72\left(\mathrm{~d}, 8 \mathrm{H}, \mathrm{ArH},{ }^{3} \mathrm{~J}=9 \mathrm{~Hz}\right)$, 7.09 (d, 4H, TTFCH=CHAr, $\left.{ }^{3} \mathrm{~J}=16 \mathrm{~Hz}\right), 7.39\left(\mathrm{~d}, 8 \mathrm{H}, \mathrm{ArH},{ }^{3} \mathrm{~J}=9 \mathrm{~Hz}\right) . I R(K B r) \mathrm{cm}^{-1}: 1595$, 1515, 1350, 1165. (MS, FAB+) m/e (I\%): $784\left(\mathrm{M}^{+}, 40\right), 639$ (40), 538 (60), 470 (60).

4,5-Distyrenyl-2-thioxo-1,3 dithiole (28). To a solution of diphosphonate 15 (450 mg; 1.19 $\mathrm{mmol})$ and freshly distilled benzaldehyde $(0.36 \mathrm{~mL} ; 3.55 \mathrm{mmol})$ in dry THF $(10 \mathrm{~mL})$ was added at $0^{\circ} \mathrm{C}$ a solution of $t$-BuOK $(400 \mathrm{mg} ; 3.55 \mathrm{mmol})$ in dry THF $(5 \mathrm{~mL})$. After stirring for $45 \mathrm{~min}$, the solvent was removed and the residue was purified by chromatography on silica gel using $\mathrm{CH}_{2} \mathrm{Cl}_{2}$ as the eluent affording orange crystals $\left(282 \mathrm{mg} ; 70 \%\right.$ yield). M.p. $=154-155^{\circ} \mathrm{C}$ $\left(\mathrm{CH}_{2} \mathrm{Cl}_{2}\right) .{ }^{1} \mathrm{H} N M R\left(\mathrm{CDCl}_{3}\right) \delta: 6.65\left(\mathrm{~d}, 2 \mathrm{H}, \mathrm{CH},{ }^{3} \mathrm{~J}=16 \mathrm{~Hz}\right), 7.18\left(\mathrm{~d}, 2 \mathrm{H}, \mathrm{CH},{ }^{3} \mathrm{~J}=16 \mathrm{~Hz}\right), 7.30-$ $7.60\left(\mathrm{~m}, 10 \mathrm{H}, \mathrm{H}\right.$ arom.). ${ }^{13} \mathrm{C} N M R\left(\mathrm{CDCl}_{3}\right) \delta: 116.7(\mathrm{~S}-\mathrm{C}-\underline{\mathrm{CH}}=\mathrm{CH}-\mathrm{C}), 127.0$ and 129.1 (C$\underline{\mathrm{CH}}=\underline{\mathrm{CH}}-\mathrm{CH}), 129.2(\mathrm{~S}-\mathrm{C}-\mathrm{CH}=\underline{\mathrm{CH}}-\mathrm{C}), 134.6(\mathrm{~S}-\underline{\mathrm{C}}-\mathrm{CH}=\mathrm{CH}-\mathrm{C}), 135.8(\mathrm{C}-\mathrm{CH}=\mathrm{CH}-\underline{\mathrm{CH}}), 139.2$ $(\underline{\mathrm{C}}-\mathrm{CH}=\mathrm{CH}-\mathrm{CH}), 208.6(\mathrm{C}=\mathrm{S}) . I R(\mathrm{KBr}) \mathrm{cm}^{-1}: 1068(\mathrm{C}=\mathrm{S}) . M S$ EI m/e $\left.(I \%): 338{\left(\mathrm{M}^{+},\right.}^{+}, 60\right), 261$ (56), 229 (41), 228 (40).

2,3-Distyrenyl-6,7-bis(methylsulfanyl)tetrathiafulvalene (29). A solution of $n$-BuLi 1.4 M in hexane $(0.26 \mathrm{~mL} ; 0.37 \mathrm{mmol})$ was added dropwise at $-78{ }^{\circ} \mathrm{C}$ under argon to a solution of phosphonate 16 (90 mg, $0.166 \mathrm{mmol})$ in dry THF $(4 \mathrm{~mL})$. After stirring for $15 \mathrm{~min}$ at $-78^{\circ} \mathrm{C}$, freshly distilled benzaldehyde $(50 \mu \mathrm{L} ; 0.5 \mathrm{mmol})$ was added dropwise. After stirring for $2 \mathrm{~h}$ at 
room temperature, the solvent was removed. The residue was purified by chromatography on silica gel using petroleum ether/ $\mathrm{CH}_{2} \mathrm{Cl}_{2}(4 / 1)$ as the mixture of eluents affording red crystals (25 $\mathrm{mg} ; 30 \%$ yield). ${ }^{l} H$ NMR $\left(C D C l_{3}\right) \delta: 2.45$ (s, $\left.6 \mathrm{H}, \mathrm{CH}_{3} \mathrm{~S}\right), 6.58\left(\mathrm{~d}, 2 \mathrm{H}, \mathrm{S}-\mathrm{C}-\mathrm{CH}=\mathrm{CH},{ }^{3} \mathrm{~J}=15.7\right.$ $\mathrm{Hz}), 7.22\left(\mathrm{~d}, 2 \mathrm{H}, \mathrm{S}-\mathrm{C}-\mathrm{CH}=\mathrm{C} \underline{\mathrm{H}},{ }^{3} \mathrm{~J}=15.7 \mathrm{~Hz}\right), 7.28-7.50\left(\mathrm{~m}, 12 \mathrm{H}, \mathrm{C}_{6} \underline{\mathrm{H}}_{5}-\mathrm{C} \underline{\mathrm{H}}=\right) .{ }^{13} \mathrm{C} N M R\left(\mathrm{CDCl}_{3}\right)$ $\delta: 19.9\left(\mathrm{CH}_{3} \mathrm{~S}\right), 110.8($ cent. $\mathrm{C}=\mathrm{C}), 118.5(\mathrm{~S}-\mathrm{C}-\underline{\mathrm{CH}}=), 128.1\left(\mathrm{~S}_{2} \mathrm{C}=\mathrm{CS}_{2}\right), 127.4$ and $129.1(\mathrm{CH}-$

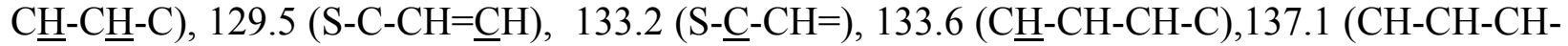
C).

2,3,6,7-Tetrastyrenyltetrathiafulvalene (30). To a solution of compound 22 (208 mg; 0.53 $\mathrm{mmol})$ in acetic anhydride $(1.2 \mathrm{~mL})$ was added at $0^{\circ} \mathrm{C} \mathrm{HBF}_{4} \cdot \mathrm{Et}_{2} \mathrm{O} 54 \%(0.15 \mathrm{~mL} ; 0.57 \mathrm{mmol})$. The reaction mixture was stirred for $4 \mathrm{~h}$ at room temperature. After dilution with dry $\mathrm{Et}_{2} \mathrm{O}(25$ $\mathrm{mL}$ ), the dithiolium salt 23 was crystallized overnight at $-18^{\circ} \mathrm{C}$. The precipitate was filtered. After dissolution in dry $\mathrm{CH}_{3} \mathrm{CN}(1.8 \mathrm{~mL})$, triethylamine $(0.8 \mathrm{~mL})$ was added. After stirring for 15 min, the reaction mixture was diluted with $\mathrm{CH}_{2} \mathrm{Cl}_{2}$, washed with brine and the organic layer was dried and concentrated. In this case, compound $\mathbf{1 7}$ was used without further purification. After addition of dry THF $(1.3 \mathrm{~mL})$, freshly distilled benzaldehyde $(0.12 \mathrm{~mL} ; 1.15 \mathrm{mmol})$ and a solution of $t$-BuOK $(129 \mathrm{mg} ; 1.15 \mathrm{mmol})$ in dry THF $(0.7 \mathrm{~mL})$ were added successively. After stirring for $30 \mathrm{~min}$ at room temperature, the purple precipitate was filtered and washed with THF (65 mg; 40\% yield for three steps); Spectroscopic analyses were in agreement with reported data for compound 30, previously synthesized from tetraformylTTF 4 and the corresponding phosphonium salt in a Wittig-type reaction. ${ }^{13 \mathrm{~b}}$

Bis-TTF (31). To a solution of diphosphonate $15(58 \mathrm{mg} ; 0.15 \mathrm{mmol})$ and monoformylTTF 2 (200 mg; $0.46 \mathrm{mmol})$ in dry THF $(1 \mathrm{~mL})$ was added at $0^{\circ} \mathrm{C}$ a solution of $t$-BuOK $(51 \mathrm{mg} ; 0.46$ $\mathrm{mmol})$ in dry THF $(0.5 \mathrm{~mL})$. After stirring for $30 \mathrm{~min}$, the solvent was removed and the residue was purified by chromatography on silica gel using $\mathrm{CS}_{2}$ as the eluent. After precipitation using a mixture of $\mathrm{CH}_{2} \mathrm{Cl}_{2} / \mathrm{MeOH}$ then filtration, $120 \mathrm{mg}$ (79\% yield) of black crystals were isolated (bordeaux in solution). M.p. $=41-42^{\circ} \mathrm{C} .{ }^{1} \mathrm{H} \mathrm{NMR}\left(\mathrm{CDCl}_{3}\right) \delta: 0.91$ and $0.92\left(2 \mathrm{t}, 12 \mathrm{H}, \mathrm{CH}_{3}-\mathrm{CH}_{2}\right.$, $\left.{ }^{3} \mathrm{~J}=7 \mathrm{~Hz}\right), 1.22-1.44\left(\mathrm{~m}, 16 \mathrm{H}, \mathrm{CH}_{3}-\mathrm{C}_{2}-\mathrm{C}_{2}\right), 1.66\left(\mathrm{q}, 8 \mathrm{H}, \mathrm{C}_{2}-\mathrm{CH}_{2} \mathrm{~S},{ }^{3} \mathrm{~J}=7 \mathrm{~Hz}\right), 2.84$ and 2.85 $\left(2 \mathrm{t}, 8 \mathrm{H}, \mathrm{CH}_{2} \mathrm{~S},{ }^{3} \mathrm{~J}=7 \mathrm{~Hz}\right), 6.25\left(\mathrm{~d}, 2 \mathrm{H}, \mathrm{S}-\mathrm{C}-\mathrm{C} \underline{\mathrm{H}}=\mathrm{CH}-\mathrm{C}=\mathrm{CH},{ }^{3} \mathrm{~J}=15 \mathrm{~Hz}\right), 6.40(\mathrm{~d}, 2 \mathrm{H}, \mathrm{S}-\mathrm{C}-$ $\left.\mathrm{CH}=\mathrm{CH}-\mathrm{C}=\mathrm{CH},{ }^{3} \mathrm{~J}=15 \mathrm{~Hz}\right), 6.55(\mathrm{~s}, 2 \mathrm{H}, \mathrm{S}-\mathrm{C}-\mathrm{CH}=\mathrm{CH}-\mathrm{C}=\mathrm{CH}) .{ }^{13} \mathrm{C} \mathrm{NMR} \quad\left(\mathrm{CDCl}_{3}\right) \delta: 13.9$ and $14.0\left(\underline{\mathrm{CH}}_{3}-\mathrm{CH}_{2}\right), 22.1$ and $22.2\left(\mathrm{CH}_{3}-\underline{\mathrm{C}} \mathrm{H}_{2}\right), 29.3$ and $29.4\left(\underline{\mathrm{C}} \mathrm{H}_{2}-\mathrm{CH}_{2} \mathrm{~S}\right), 30.6\left(\mathrm{CH}_{3}-\mathrm{CH}_{2}-\underline{\mathrm{CH}}_{2}\right)$, 36.2 and $36.3\left(\mathrm{CH}_{2} \mathrm{~S}\right), 110.3$ and 110.8 (cent. $\left.\mathrm{C}=\mathrm{C}\right), 118.1(\mathrm{~S}-\mathrm{C}-\mathrm{CH}=\mathrm{CH}-\mathrm{C}=\mathrm{CH}), 123.6(\mathrm{~S}-\mathrm{C}-$ $\mathrm{CH}=\mathrm{CH}-\mathrm{C}=\underline{\mathrm{CH}}$ ), 125.4 (S-C-CH=$\underline{\mathrm{CH}}-\mathrm{C}=\mathrm{CH}$ ), 127.6 and 128.0 (PentS- $\underline{\mathrm{C}}$ ), 134.3 (S- $\underline{\mathrm{C}}-\mathrm{CH}=\mathrm{CH}-$ $\mathrm{C}=\mathrm{CH}), 138.6(\mathrm{~S}-\mathrm{C}-\mathrm{CH}=\mathrm{CH}-\underline{\mathrm{C}}=\mathrm{CH}), 206.5(\mathrm{C}=\mathrm{S})$. Elemental analysis for $\mathrm{C}_{39} \mathrm{H}_{50} \mathrm{~S}_{15}$ (997.97) calcd. C 46.85 H 5.04 S 48.11; found C 45.66 H 5.00 S 47.41.

Tris-TTF (32). To a solution of diphosphonate $16(53 \mathrm{mg} ; 0.1 \mathrm{mmol})$ and monoformylTTF 2 $(130 \mathrm{mg} ; 0.29 \mathrm{mmol})$ in dry THF $(4 \mathrm{~mL})$ was added at $0^{\circ} \mathrm{C}$ a solution of $t$-BuOK $(32 \mathrm{mg} ; 0.29$ $\mathrm{mmol})$ in dry THF $(3 \mathrm{~mL})$. After stirring for $2 \mathrm{~h}$, the solvent was removed and the residue was purified by chromatography on silica gel using $\mathrm{CS}_{2}$ as the eluent. After precipitation using a mixture of $\mathrm{CH}_{2} \mathrm{Cl}_{2} / \mathrm{MeOH}$ then filtration, $63 \mathrm{mg}$ (55\% yield) of purple crystals were isolated. M.p. $=70-75^{\circ} \mathrm{C} .{ }^{1} H N M R\left(\mathrm{CDCl}_{3}\right) \delta: 0.90$ and $0.91\left(2 \mathrm{t}, 12 \mathrm{H}, \mathrm{CH}_{3}-\mathrm{CH}_{2},{ }^{3} \mathrm{~J}=7 \mathrm{~Hz}\right), 1.22-1.44$ 
(m, 16H, $\mathrm{CH}_{3}-\mathrm{CH}_{2}-\mathrm{CH}_{2}$ ), $1.64\left(\mathrm{qu}, 8 \mathrm{H}, \underline{\mathrm{CH}}_{2}-\mathrm{CH}_{2} \mathrm{~S},{ }^{3} \mathrm{~J}=7 \mathrm{~Hz}\right), 2.43\left(\mathrm{~s}, 6 \mathrm{H}, \mathrm{CH}_{3} \mathrm{~S}\right), 2.82$ and 2.85 $\left(2 \mathrm{t}, 8 \mathrm{H}, \mathrm{CH}_{2} \mathrm{~S},{ }^{3} \mathrm{~J}=7 \mathrm{~Hz}\right), 6.31\left(\mathrm{~d}, 2 \mathrm{H}, \mathrm{S}-\mathrm{C}-\mathrm{CH}=\mathrm{CH}-\mathrm{C}=\mathrm{CH},{ }^{3} \mathrm{~J}=15 \mathrm{~Hz}\right), 6.32(\mathrm{~d}, 2 \mathrm{H}, \mathrm{S}-\mathrm{C}-$ $\left.\mathrm{CH}=\mathrm{CH}-\mathrm{C}=\mathrm{CH},{ }^{3} \mathrm{~J}=15 \mathrm{~Hz}\right), 6.44(\mathrm{~s}, 2 \mathrm{H}, \mathrm{S}-\mathrm{C}-\mathrm{CH}=\mathrm{CH}-\mathrm{C}=\mathrm{C} \underline{\mathrm{H}}) .{ }^{13} \mathrm{CNMR} \quad\left(\mathrm{CDCl}_{3}\right) \delta: 14.6$

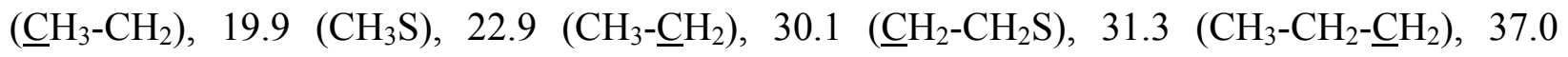
$\left(\mathrm{CH}_{2} \mathrm{~S}\right), 109.0$ and 112.1 (cent. $\mathrm{C}=\mathrm{C}$ TTF), 110.6 and 112.3 (cent. $\mathrm{C}=\mathrm{C}$ lateral TTF), 120.4 (S-C$\underline{\mathrm{CH}}=\mathrm{CH}-\mathrm{C}=\mathrm{CH}), 122.0 \quad(\mathrm{~S}-\mathrm{C}-\mathrm{CH}=\mathrm{CH}-\mathrm{C}=\underline{\mathrm{CH}}), 125.0 \quad(\mathrm{~S}-\mathrm{C}-\mathrm{CH}=\underline{\mathrm{CH}}-\mathrm{C}=\mathrm{CH}), 128.1 \quad\left(\mathrm{CH}_{3} \mathrm{~S}-\underline{\mathrm{C}}\right)$, 128.5 and 128.7 (PentS- $\underline{\mathrm{C}}), 133.2(\mathrm{~S}-\underline{\mathrm{C}}-\mathrm{CH}=\mathrm{CH}-\mathrm{C}=\mathrm{CH}), 135.6(\mathrm{~S}-\mathrm{C}-\mathrm{CH}=\mathrm{CH}-\underline{\mathrm{C}}=\mathrm{CH}) . M S$ m/e $F A B^{+}$(m-NBA) (I\%): $1160\left(\mathrm{M}^{+}, 20\right), 778(17), 350$ (100).

2-Thioxo-naphtho[2,3-d][1,3]dithiole-5,8-dione (34). To a solution of compound $\mathbf{1 9}^{14}(1.10 \mathrm{~g}$; $3.43 \mathrm{mmol})$ in dry $\mathrm{CH}_{3} \mathrm{CN}(60 \mathrm{~mL})$ was added $p$-benzoquinone $(0.38 \mathrm{~g} ; 3.5 \mathrm{mmol})$ then tetraethylammonium iodide $(2.77 \mathrm{~g} ; 11 \mathrm{mmol})$. The resulting mixture was refluxed under nitrogen for $45 \mathrm{~min}$. After addition of DDQ (1.62 $\mathrm{g} ; 7.1 \mathrm{mmol})$, the solution was again refluxed for $7 \mathrm{~h}$. The solvent was removed in vacuo and compound 34 was precipitated by addition of $\mathrm{MeOH}(150 \mathrm{~mL})$. The precipitate was filtered, then washed with $\mathrm{MeOH}(100 \mathrm{~mL})$, water $(100$ $\mathrm{mL})$ and $\mathrm{Et}_{2} \mathrm{O}(100 \mathrm{~mL})$. At this step of purification, the crude material can be used without further purification for subsequent Diels-Alder cycloaddition with cyclopentadiene (see the synthesis of compound 35).

In order to improve its purity, the resulting material was dissolved in $\mathrm{CH}_{2} \mathrm{Cl}_{2}$, filtered on silica gel using $\mathrm{CH}_{2} \mathrm{Cl}_{2}$ as the eluent. The filtrate was washed with an aqueous solution of sodium thiosulfate, dried $\left(\mathrm{MgSO}_{4}\right)$ and concentrated to afford compound 34 as yellow-orange crystals. M.p. $=240-242^{\circ} \mathrm{C}\left(\mathrm{CH}_{2} \mathrm{Cl}_{2}\right) .{ }^{1} H N M R\left(\mathrm{CDCl}_{3}\right) \delta: 7.05$ (s, 2H, H-C=C-H), $8.16(\mathrm{~s}, 2 \mathrm{H}, \mathrm{H}-\mathrm{C}=\mathrm{C}-$ CO). IR (KBr) cm $\mathrm{cm}^{-1}: 1657(\mathrm{C}=\mathrm{O}), 1076(\mathrm{C}=\mathrm{S}) . M S$ EI m/e (I\%) : $264\left(\mathrm{M}^{+}, 100\right), 220(45), 192$ (18).

Compound (35). To a suspension of compound 34 (1.15 g; 4,35 mmol) in dry THF (100 mL) was added freshly distilled cyclopentadiene $(1,78 \mathrm{~mL} ; 22 \mathrm{mmol})$. The reaction mixture was stirred overnight at room temperature. The solvent was removed in vacuo and the residue was purified by chromatography on silica gel using $\mathrm{CH}_{2} \mathrm{Cl}_{2}$ as the eluent to furnish yellow crystals (1.21 g; $59 \%$ yield calculated from 19). M.p. $=198^{\circ} \mathrm{C}$ (The temperature of the retroDiels-Alder reaction from 35 was determined to start at $198^{\circ} \mathrm{C}$ with the formation of compound 34 as yelloworange crystals for which the melting point was noted at $\left.240-242^{\circ} \mathrm{C}\right) .{ }^{1} \mathrm{HNMR}\left(\mathrm{CDCl}_{3}\right) \delta: 1.50$ $1.60\left(\mathrm{~m}, 2 \mathrm{H}, \mathrm{CH}_{2}\right), 3.50\left(\mathrm{dd}, 2 \mathrm{H}, \mathrm{CH}-\mathrm{C}=\mathrm{O},{ }^{3} \mathrm{~J}=2 \mathrm{~Hz},{ }^{3} \mathrm{~J}=1.5 \mathrm{~Hz}\right), 3.65-3.72\left(\mathrm{~m}, 2 \mathrm{H}, \mathrm{C} \underline{\mathrm{H}}-\mathrm{CH}_{2}\right)$, $5.97\left(\mathrm{t}, 2 \mathrm{H}, \mathrm{H}-\mathrm{C}=\mathrm{C}-\mathrm{H},{ }^{3} \mathrm{~J}=2 \mathrm{~Hz}\right), 8.06(\mathrm{~s}, 2 \mathrm{H}, \mathrm{H}-\mathrm{C}=\mathrm{C}-\mathrm{C}=\mathrm{O}) .{ }^{13} \mathrm{C} \mathrm{NMR}\left(\mathrm{CDCl}_{3}\right) \delta: 50.1\left(\mathrm{CH}_{2}\right)$, 50.2 and $50.6(\mathrm{CO}-\underline{\mathrm{C}} \mathrm{H}-\underline{\mathrm{C}} \mathrm{H}), 120.5(\mathrm{H}-\underline{\mathrm{C}}=\mathrm{C}-\mathrm{C}=\mathrm{O}), 134.7(\mathrm{H}-\mathrm{C}=\underline{\mathrm{C}}-\mathrm{C}=\mathrm{O}), 136.3(\mathrm{H}-\mathrm{C}=\mathrm{C}-\mathrm{H})$, $148.2(\mathrm{~S}-\mathrm{C}=\mathrm{C}-\mathrm{S}), 196.8(\mathrm{C}=\mathrm{O}), 224.0(\mathrm{C}=\mathrm{S}) . I R(\mathrm{KBr}) \mathrm{cm}^{-1}: 1674(\mathrm{C}=\mathrm{O}), 1055(\mathrm{C}=\mathrm{S}) . M S E I$ $m / e(I \%): 330\left(\mathrm{M}^{+}, 35\right), 264$ (100), 220 (39), 66 (37). Elemental analysis for $\mathrm{C}_{16} \mathrm{H}_{10} \mathrm{O}_{2} \mathrm{~S}_{3}$ (329.98) calcd. C 58.16, H 3.05, S 29.11; found : C 57.41, H 3.08, S 28.74.

4,5-Bis(pentylsulfanyl)-2-dimethyloxyphosphoryl-2-yl-1,3-dithiole (36). Phosphonate 36 was prepared as beige crystals according to the reported procedure. ${ }^{7 \mathrm{f}} \mathrm{M} . \mathrm{p} .=47^{\circ} \mathrm{C}(\mathrm{EtOAc} /$ petroleum ether). ${ }^{1} \mathrm{HNMR}\left(\mathrm{CDCl}_{3}\right) \delta: 0.91\left(\mathrm{t}, 6 \mathrm{H}, \mathrm{C}_{3} \mathrm{CH}_{2},{ }^{3} \mathrm{~J}=7 \mathrm{~Hz}\right), 1.25-1.50\left(\mathrm{~m}, 8 \mathrm{H}, \mathrm{CH}_{3} \underline{\mathrm{C}}_{2} \mathrm{C}_{2}\right)$, 1.60-1.80 (m, 4H, $\left.\underline{\mathrm{CH}}_{2} \mathrm{CH}_{2} \mathrm{~S}\right), 2.75\left(\mathrm{ddd}, 2 \mathrm{H}, \underline{\mathrm{CH}}_{\mathrm{a}} \mathrm{H}_{\mathrm{b}} \mathrm{S},{ }^{2} \mathrm{~J}=12.8 \mathrm{~Hz},{ }^{3} \mathrm{~J}=6.7 \mathrm{~Hz}\right.$ and $\left.{ }^{3} \mathrm{~J}=7.7 \mathrm{~Hz}\right)$, 
$2.88\left(\mathrm{ddd}, 2 \mathrm{H}, \mathrm{CH}_{\mathrm{a}} \underline{\mathrm{H}}_{\mathrm{b}} \mathrm{S},{ }^{2} \mathrm{~J}=12.8 \mathrm{~Hz},{ }^{3} \mathrm{~J}=6.7 \mathrm{~Hz}\right.$ and $\left.{ }^{3} \mathrm{~J}=7.7 \mathrm{~Hz}\right), 3.87\left(\mathrm{~d}, 6 \mathrm{H}, \mathrm{CH}_{3} \mathrm{O},{ }^{3} \mathrm{~J}_{\mathrm{H}-}\right.$ $\left.{ }_{\mathrm{P}}=10.6 \mathrm{~Hz}\right), 4.74\left(\mathrm{~d}, 1 \mathrm{H}, \mathrm{CH},{ }^{2} \mathrm{~J}_{\mathrm{H}-\mathrm{P}}=5.5 \mathrm{~Hz}\right) .{ }^{13} \mathrm{CNMR}\left(\mathrm{CDCl}_{3}\right) \delta: 13.8\left(\underline{\mathrm{CH}}_{3} \mathrm{CH}_{2}\right), 22.0$ $\left(\mathrm{CH}_{3} \underline{\mathrm{CH}}_{2}\right), 29.2\left(\underline{\mathrm{CH}}_{2} \mathrm{CH}_{2} \mathrm{~S}\right), 30.5\left(\mathrm{CH}_{3} \mathrm{CH}_{2} \underline{\mathrm{CH}}_{2}\right), 36.0\left(\mathrm{CH}_{2} \mathrm{~S}\right), 41.0\left(\mathrm{~d}, \mathrm{CH}-\mathrm{P},{ }^{1} \mathrm{~J}_{\mathrm{C}-\mathrm{P}}=160 \mathrm{~Hz}\right)$, $54.4\left(\mathrm{~d}, \mathrm{CH}_{3} \mathrm{O},{ }^{2} \mathrm{~J}_{\mathrm{C}-\mathrm{P}}=7.2 \mathrm{~Hz}\right), 125.3(\mathrm{C}=\mathrm{C}) . M S E I m / e(I \%): 416\left(\mathrm{M}^{+}, 22\right), 307(100), 237$ (19), 167 (19), 43 (42). Elemental analysis for $\mathrm{C}_{15} \mathrm{H}_{29} \mathrm{O}_{3} \mathrm{PS}_{4}$ (416.07) calcd. C 43.24, H 7.02, S 30.79; found : C 43.36, H 6.81, S 30.92.

Compound (37). To a solution of phosphonate 36 (1.13 g; $2.72 \mathrm{mmol})$ in dry THF (20 mL) was added dropwise at $-78^{\circ} \mathrm{C}$ under argon $n$-BuLi $1.5 \mathrm{M}$ in hexane $(2.0 \mathrm{~mL} ; 3 \mathrm{mmol})$. After stirring for $15 \mathrm{~min}$ at $-78^{\circ} \mathrm{C}$, a solution of compound $35(300 \mathrm{mg}$; $0.91 \mathrm{mmol})$ in dry THF (15 mL) was added dropwise. The reaction mixture was stirred for $2 \mathrm{~h}$ until the temperature arose to progressively $-20^{\circ} \mathrm{C}$. After addition of $\mathrm{MeOH}$, the precipitate was filtered, then washed with $\mathrm{MeOH}$ and compound 37 was isolated as yellow lemon crystals (767 mg; 93\% yield). M.p. =

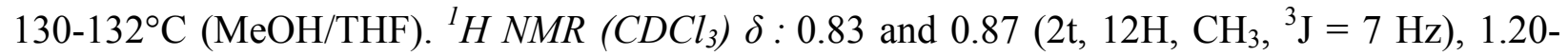
1.80 (m, 26H, $\left.\mathrm{CH}_{3}-\underline{\mathrm{CH}}_{2}-\underline{\mathrm{C}}_{2}-\underline{\mathrm{C}}_{2}, \mathrm{CH}-\underline{\mathrm{C}}_{2}\right)$, 2.60-2.92 (m, 8H, $\left.\mathrm{CH}_{2} \mathrm{~S}\right), 3.04$ (br.s., $2 \mathrm{H},=\mathrm{C}-\mathrm{CH}-$ $\mathrm{CH}$ ), 3.32 (br.s., $2 \mathrm{H},=\mathrm{C}-\mathrm{C} \underline{\mathrm{H}}-\mathrm{CH}$ ), 5.41 (br.s., $2 \mathrm{H}, \mathrm{H}-\mathrm{C}=\mathrm{C}-\mathrm{H}), 7.24$ (s, 2H, S-C=CH-C). ${ }^{13} \mathrm{C}$ NMR $\left(\mathrm{CDCl}_{3}\right) \delta: 14.6\left(\mathrm{CH}_{3}\right), 22.8\left(\mathrm{CH}_{3}-\mathrm{CH}_{2}\right), 30.0$ and $30.1\left(\mathrm{CH}_{3}-\mathrm{CH}_{2}-\mathrm{CH}_{2}-\mathrm{CH}_{2}\right), 31.3$ and $31.4\left(\mathrm{CH}_{3}-\mathrm{CH}_{2}-\mathrm{CH}_{2}-\mathrm{CH}_{2}\right), 36.9\left(\mathrm{CH}_{2} \mathrm{~S}\right), 47.7$ (=C- $\left.\underline{\mathrm{CH}}-\mathrm{CH}\right), 49.2$ (=C-CH- $\left.\underline{\mathrm{CH}}\right), 50.5$ (=C-CH$\left.\mathrm{CH}-\underline{\mathrm{CH}}_{2}\right), 118.7(\mathrm{~S}-\mathrm{C}=\underline{\mathrm{C}} \mathrm{H}-\mathrm{C}), 123.9\left(\mathrm{~S}_{2} \underline{\mathrm{C}}=\mathrm{C}-\mathrm{C}\right), 126.7$ and $127.4\left(\mathrm{~S}_{2} \mathrm{C}=\mathrm{CS}_{2}\right), 130.9\left(\mathrm{~S}{ }_{2} \mathrm{C}=\underline{\mathrm{C}}-\mathrm{C}\right)$, $135.2(\mathrm{H}-\mathrm{C}=\mathrm{C}-\mathrm{H}), 136.4(\mathrm{~S}-\underline{\mathrm{C}}=\mathrm{CH}-\mathrm{C}), 139.4(\mathrm{~S}-\mathrm{C}=\mathrm{CH}-\underline{\mathrm{C}}), 211.8(\mathrm{C}=\mathrm{S}) . I R(\mathrm{KBr}) \mathrm{cm}^{-1}: 1060$ $(\mathrm{C}=\mathrm{S}) . M S F A B^{+}$m/e (I\%) : $911\left((\mathrm{M}+\mathrm{H})^{+}, 10\right), 844$ (100), 612 (27), 582 (39), 538 (33), 329 (46). Elemental analysis for $\mathrm{C}_{42} \mathrm{H}_{54} \mathrm{~S}_{11}$ (910.12) calcd. C 55.34, H 5.97; found : C 55.06, H 6.10.

Compound (18). A solution of compound 37 (200 mg; $0.22 \mathrm{mmol})$ in trimethylphosphite $(2 \mathrm{~mL})$ was heated at $140^{\circ} \mathrm{C}$ for $1 \mathrm{~h}$. The solution was cooled then concentrated in vacuo. The residue was purified by chromatography on silica gel using petroleum ether $/ \mathrm{CH}_{2} \mathrm{Cl}_{2}(7 / 3)$ as the mixture of eluents to afford TTF 38 as orange crystals ( $40 \mathrm{mg} ; 21 \%$ yield), then the oxo derivative 39 as orange crystals ( $9 \mathrm{mg} ; 4 \%$ yield). Elution using petroleum ether/EtOAc $(1 / 1)$ as the mixture of eluents afforded an orange oil corresponding to phosphonate 18 (77 mg; 35\% yield) which was isolated as a mixture of two stereoisomers in a 68/32 ratio. ${ }^{1} H N M R\left(C D C l_{3}\right) \delta: 0.85-0.95(\mathrm{~m}$, $12 \mathrm{H}, \mathrm{C}_{3}-\mathrm{CH}_{2}$ ), 1.28-1.55 (m, $\left.18 \mathrm{H}, \mathrm{CH}_{3}-\underline{\mathrm{CH}}_{2}-\underline{\mathrm{CH}}_{2}-\mathrm{CH}_{2}, \mathrm{CH}-\underline{\mathrm{C}}_{2}\right), 1.57-1.70$ (m, 8H, $\mathrm{CH}_{3}-\mathrm{CH}_{2}-$ $\mathrm{CH}_{2}-\underline{\mathrm{C}}_{2}$ ), 2.75-2.92 (m, 8H, $\mathrm{CH}_{2} \mathrm{~S}$ ), 3.25 (br.s., $2 \mathrm{H}$, =C-CH-C프), 3.31 (br.s., $2 \mathrm{H},=\mathrm{C}-\mathrm{C} \underline{\mathrm{H}}-\mathrm{CH}$ ), $3.79(68 \%)$ and $3.83(32 \%)\left(2 \mathrm{~d}, 6 \mathrm{H}, \mathrm{CH}_{3} \mathrm{O},{ }^{3} \mathrm{~J}_{\mathrm{H}-\mathrm{P}}=10.5 \mathrm{~Hz}\right), 4.90(68 \%)$ and $5.05(32 \%)(2 \mathrm{~d}$, $\left.1 \mathrm{H}, \mathrm{H}-\mathrm{C}-\mathrm{P},{ }^{2} \mathrm{~J}_{\mathrm{H}-\mathrm{P}}=5.2 \mathrm{~Hz}\right), 5.43(68 \%)$ and 5,45 (32\%) $\left(2 \mathrm{t}, 2 \mathrm{H}, \mathrm{H}-\mathrm{C}=\mathrm{C}-\mathrm{H},{ }^{3} \mathrm{~J}=1.6 \mathrm{~Hz},{ }^{3} \mathrm{~J}=1.6\right.$ $\mathrm{Hz}), 7.05$ (68\%) and $7.13(32 \%)\left(\mathrm{s}, 2 \mathrm{H}, \mathrm{CH}\right.$ arom). ${ }^{13} \mathrm{CNMR}\left(\mathrm{CDCl}_{3}\right) \delta: 14.6\left(\mathrm{CH}_{3}\right), 22.8\left(\mathrm{CH}_{3}-\right.$ $\left.\mathrm{CH}_{2}\right), 30.0\left(\mathrm{CH}_{3}-\mathrm{CH}_{2}-\mathrm{CH}_{2}-\underline{C H}_{2}\right), 31.3\left(\mathrm{CH}_{3}-\mathrm{CH}_{2}-\mathrm{CH}_{2}-\mathrm{CH}_{2}\right), 36.8\left(\mathrm{CH}_{2} \mathrm{~S}\right), 44.8\left(\mathrm{~d}, \mathrm{H}-\mathrm{C}-\mathrm{P},{ }^{1} \mathrm{~J}_{\mathrm{C}-\mathrm{P}}\right.$ $=159 \mathrm{~Hz}), 47.6(=\mathrm{C}-\underline{\mathrm{C}} \mathrm{H}-\mathrm{CH}), 48.8(=\mathrm{C}-\mathrm{CH}-\underline{\mathrm{CH}}), 50.3\left(=\mathrm{C}-\mathrm{CH}-\mathrm{CH}-\underline{\mathrm{CH}}_{2}\right), 55.1$ and 55.3 $\left(\mathrm{CH}_{3} \mathrm{O}\right), 119.5$ and $119.9(\mathrm{~S}-\mathrm{C}=\underline{\mathrm{CH}}-\mathrm{C}), 124.5$ and $124.7\left(\mathrm{~S}_{2} \underline{\mathrm{C}}=\mathrm{C}-\mathrm{C}\right), 126.8$ and $127.0\left(\mathrm{~S}_{2} \mathrm{C}=\mathrm{CS}_{2}\right)$, $128.6\left(\mathrm{~S}_{2} \mathrm{C}=\underline{\mathrm{C}}-\mathrm{C}\right), 134.7$ and $134.9(\mathrm{~S}-\underline{\mathrm{C}}=\mathrm{CH}-\underline{\mathrm{C}}), 135.2(\mathrm{H}-\mathrm{C}=\mathrm{C}-\mathrm{H}) . I R(\mathrm{KBr}) \mathrm{cm}^{-1}: 1260(\mathrm{P}=\mathrm{O})$, 1034 (P-O-C). MS FAB ${ }^{+}$m-NBA m/e (I\%) : 989 ((M+H) $\left.{ }^{+}, 10\right), 922$ (100), 813 (17), 660 (15), 616 (7), 551 (7). MS Maldi-Tof m/e (I\%) : $922\left(\mathrm{M}-\mathrm{C}_{5} \mathrm{H}_{6}, 100\right)$. Elemental analysis for $\mathrm{C}_{44} \mathrm{H}_{61} \mathrm{O}_{3} \mathrm{~S}_{10} \mathrm{P}(988.16)$ calcd. C 53.40, H 6.21; S 32.40; found : C 53.03, H 6.18; S 31.44. 
Compound (41). To a solution of phosphonate 18 (245 mg; $0.25 \mathrm{mmol})$ in dry THF (6 mL) was added dropwise at $-78{ }^{\circ} \mathrm{C}$ under argon $n$-BuLi $1.5 \mathrm{M}$ in hexane $(0.17 \mathrm{~mL} ; 0.25 \mathrm{mmol})$. After stirring for $15 \mathrm{~min}$ at $-78^{\circ} \mathrm{C}$, a solution of 1,4-terephthaldehyde $(11 \mathrm{mg} ; 0.08 \mathrm{mmol})$ in dry THF $(1 \mathrm{~mL})$ was added dropwise. The reaction mixture was stirred for $3 \mathrm{~h}$ at room temperature then concentrated in vacuo. The residue was purified by chromatography on silica gel using petroleum ether/ $\mathrm{CH}_{2} \mathrm{Cl}_{2}(4 / 1)$ as the mixture of eluents to afford extended-TTF 41 as orange crystals (78 mg; $51 \%$ yield). Elution with $\mathrm{CH}_{2} \mathrm{Cl}_{2}$ furnished compound $\mathbf{4 0}$ as red crystals (12 mg; 15\% yield). Compound 41 was isolated as a mixture of cis/trans stereoisomers in a ratio : 50/50. ${ }^{1} \mathrm{H} \mathrm{NMR}\left(\mathrm{CDCl}_{3}\right) \delta: 0.88$ and 0,92 (2t, $\left.24 \mathrm{H}, \mathrm{CH}_{3}\right), 1.10-1.50\left(\mathrm{~m}, 40 \mathrm{H}, \mathrm{CH}_{3}-\underline{\mathrm{C}}_{2}-\mathrm{C}_{2}, \mathrm{C}_{2}-\mathrm{CH}\right)$, 1.50-1.80 (m, 16H, $\left.\underline{\mathrm{C}}_{2}-\mathrm{CH}_{2}-\mathrm{S}\right), 1.70-1.95\left(16 \mathrm{H}, \mathrm{CH}_{2} \mathrm{~S}\right), 3.07$ (br.s., $\left.4 \mathrm{H},=\mathrm{C}-\mathrm{CH}-\mathrm{C} \underline{\mathrm{H}}-\mathrm{CH}_{2}\right), 3.34$ (br.s., $4 \mathrm{H},=\mathrm{C}-\mathrm{C} \underline{H}-\mathrm{CH}-\mathrm{CH}_{2}$ ), 5.48 (br.s., $\left.4 \mathrm{H}, \mathrm{CH}-\mathrm{C} \underline{\mathrm{H}}=\mathrm{C} \underline{\mathrm{H}}-\mathrm{CH}\right), 6.56$ (s, 2H, H-C=CS ), 7.11 and $7.13(2 \mathrm{~s}, 4 \mathrm{H}, \mathrm{S}-\mathrm{C}-\mathrm{CH}=\mathrm{C}), 7.35(\mathrm{~d}, 1 \mathrm{H}, \mathrm{C}=\mathrm{C} \underline{\mathrm{H}}-\mathrm{C} \underline{\mathrm{H}}=\mathrm{C}) .{ }^{13} \mathrm{CNMR}\left(\mathrm{CDCl}_{3}\right) \delta: 14.6\left(\mathrm{CH}_{3}\right), 22.9$ $\left(\mathrm{CH}_{3}-\mathrm{CH}_{2}\right), 30.1\left(\mathrm{CH}_{3}-\mathrm{CH}_{2}-\mathrm{CH}_{2}-\underline{C H}_{2}\right), 31.4\left(\mathrm{CH}_{3}-\mathrm{CH}_{2}-\underline{C H}_{2}-\mathrm{CH}_{2}\right), 36.8\left(\mathrm{CH}_{2} \mathrm{~S}\right), 47.7(=\mathrm{C}-\underline{\mathrm{CH}}-$ $\mathrm{CH}), 48.9$ (=C-CH- $\underline{\mathrm{CH}}), 50.4\left(=\mathrm{C}-\mathrm{CH}-\mathrm{CH}-\underline{\mathrm{CH}}_{2}\right), 115.4\left(\mathrm{~S}_{2} \mathrm{C}=\underline{\mathrm{CH}}-\mathrm{Ar}\right), 118.3$ and 119.1 (S$\mathrm{C}=\underline{\mathrm{C}} \mathrm{H}-\mathrm{C}), 124.8$ and $124.8\left(\mathrm{~S}_{2} \underline{\mathrm{C}}=\mathrm{C}-\mathrm{C}\right), 126.8$ and $127.0 \quad\left(\mathrm{~S}_{2} \mathrm{C}=\mathrm{CS}_{2}\right), 126.9(\underline{\mathrm{C}}=\mathrm{CH}-\mathrm{CH}=\underline{\mathrm{C}})$, $127.7(\mathrm{C}=\mathrm{C} \underline{\mathrm{H}}-\mathrm{C} \underline{\mathrm{H}}=\mathrm{C}), 128.5$ and $128.6\left(\mathrm{~S}{ }_{2} \mathrm{C}=\underline{\mathrm{C}}-\mathrm{C}\right), 133.0$ and $133.4(=\mathrm{C}-\mathrm{CH}=\underline{\mathrm{CS}})_{2}, 134.9(\mathrm{H}-$ $\mathrm{C}=\mathrm{C}-\mathrm{H}), 134.5,134.7,135.2(\mathrm{~S}-\underline{\mathrm{C}}=\mathrm{CH}-\underline{\mathrm{C}}$ cis/trans$) . M S F A B^{+} m-N B A m / e(I \%): 1862\left((\mathrm{M}+\mathrm{H})^{+}\right.$, 19), 1794/1792 (M-C $\left.\mathrm{H}_{6}, 26 / 19\right), 1728 / 1726\left(\mathrm{M}-2 \mathrm{C}_{5} \mathrm{H}_{6}, 100 / 50\right), 1466$ (50), 1438 (80). Elemental analysis for $\mathrm{C}_{92} \mathrm{H}_{114} \mathrm{~S}_{20}$ (1858.33) calcd. C 59.37, H 6.17; found : C 58.66, H 6.15.

Compound (40). M.p. $=63-65^{\circ} \mathrm{C}\left(\mathrm{CH}_{2} \mathrm{Cl}_{2}\right.$ /petroleum ether). ${ }^{l} \mathrm{H} N M R\left(C D C l_{3}\right) \delta: 0.88$ and 0.92 (2t, $\left.12 \mathrm{H}, \mathrm{CH}_{3}\right), 1.10-1.50\left(\mathrm{~m}, 20 \mathrm{H}, \mathrm{CH}_{3}-\underline{\mathrm{C}}_{2}-\underline{\mathrm{C}}_{2}, \mathrm{C}_{2}-\mathrm{CH}\right), 1.50-1.80$ (m, 8H, $\left.\underline{\mathrm{C}}_{2}-\mathrm{CH}_{2} \mathrm{~S}\right)$, 1.70-1.95 (8H, $\left.\mathrm{CH}_{2} \mathrm{~S}\right), 3.07$ (br.s., $2 \mathrm{H}$, =C-CH-Cㅍ-CH ), 3.34 (br.s., $2 \mathrm{H},=\mathrm{C}-\mathrm{C} \underline{\mathrm{H}}-\mathrm{CH}-\mathrm{CH}_{2}$ ), 5.48 (br.s., $2 \mathrm{H}, \mathrm{CH}-\mathrm{C} \underline{\mathrm{H}}=\mathrm{CH}-\mathrm{CH}), 6.64\left(\mathrm{~s}, 1 \mathrm{H}, \mathrm{H}-\mathrm{C}=\mathrm{CS}_{2}\right), 7.16$ and 7.19 (2s, 2H, S-C-CH=C), 7.47 $\left(\mathrm{d}, 2 \mathrm{H}, \mathrm{CHO}-\mathrm{C}-\mathrm{CH}=\mathrm{CH},{ }^{3} \mathrm{~J}=8 \mathrm{~Hz}\right), 7.88\left(\mathrm{~d}, 2 \mathrm{H}, \mathrm{CHO}-\mathrm{C}-\mathrm{CH}=\mathrm{CH},{ }^{3} \mathrm{~J}=8 \mathrm{~Hz}\right), 9.97(\mathrm{~s}, 1 \mathrm{H}$, CHO). IR (KBr) cm ${ }^{-1}: 1695(\mathrm{C}=\mathrm{O}) . M S F A B^{+}$m/e (I\%) : $997\left((\mathrm{M}+\mathrm{H})^{+}, 16\right), 930$ (100), 668 (62), 624 (55). Elemental analysis for $\mathrm{C}_{50} \mathrm{H}_{60} \mathrm{OS}_{10}$ (996.14) calcd. C 60.19, H 6.06, S 32.14; found : C 59.24, H 6.14, S 31.78.

Compound (42). A solution of TTF 41 (75 mg; $\left.4.10^{-5} \mathrm{~mol}\right)$ in $o$-dichlorobenzene $(3 \mathrm{~mL})$ was refluxed for $15 \mathrm{~min}$. The solvent was distilled using a Kugelrohr apparatus $\left(50^{\circ} \mathrm{C}, 9 \mathrm{~mm} \mathrm{Hg}\right)$. Extended-TTF 42 was isolated as bordeaux crystals (69 mg; quantitative yield). M.p. $=70-72^{\circ} \mathrm{C}$. ${ }^{1} \mathrm{H} \mathrm{NMR}\left(\mathrm{C}_{6} \mathrm{D}_{6}, 340 \mathrm{~K}\right) \delta: 0.85-1.00\left(\mathrm{~m}, 24 \mathrm{H}, \mathrm{CH}_{3}\right), 1.00-1.80\left(\mathrm{~m}, 48 \mathrm{H}, \mathrm{CH}_{3}-\mathrm{CH}_{2}-\mathrm{CH}_{2}-\mathrm{CH}_{2}\right)$, 2.50-2.90 (m, 16H, $\left.\mathrm{CH}_{2} \mathrm{~S}\right), 6.42(\mathrm{~s}, 4 \mathrm{H}, \mathrm{H}-\mathrm{C}=\mathrm{C}-\mathrm{H}), 7.23\left(\mathrm{~s}, 2 \mathrm{H}, \mathrm{C}-\mathrm{CH}=\mathrm{CS}_{2}\right), 7.74$ and $7.78(2 \mathrm{~s}$, $4 \mathrm{H}, \mathrm{S}-\mathrm{C}=\mathrm{CH}-\mathrm{C})$, protons of the central benzene ring are masked by the peak of the solvent. $M S$ Maldi-Tof m/e: $1728\left(\mathrm{M}^{+}\right)$. Elemental analysis for $\mathrm{C}_{82} \mathrm{H}_{102} \mathrm{~S}_{20}(1726.24)$ calcd. C 56.96, H 5.95, S 37.09; found : C 56.61, H 5.89, S 36.84.

Compound (43). To a solution of phosphonate 18 (240 mg; $0.24 \mathrm{mmol})$ in dry THF (4 mL) was added dropwise at $-78{ }^{\circ} \mathrm{C}$ under argon atmosphere $n$-BuLi $2.2 \mathrm{M}$ in hexane $(0.11 \mathrm{~mL} ; 0.24$ mmol). After stirring for $15 \mathrm{~min}$ at $-78^{\circ} \mathrm{C}$, a solution of 1,3,5-triformylbenzene ${ }^{25}$ (10 mg; 0.06 $\mathrm{mmol})$ in dry THF $(1 \mathrm{~mL})$ was added dropwise. The reaction mixture was stirred for $4 \mathrm{~h}$ at room temperature then concentrated in vacuo. The residue was purified by chromatography on silica 
gel using petroleum ether/ $\mathrm{CH}_{2} \mathrm{Cl}_{2}$ (7/3) as the mixture of eluents to afford compound 43 as orange crystals (101 mg; 60\% yield). The product was isolated as a mixture of cis/trans stereoisomers in a ratio : 50/50. ${ }^{1} H N M R\left(C D C l_{3}\right) \delta: 0.80-1.10\left(\mathrm{~m}, 36 \mathrm{H}, \mathrm{CH}_{3}\right), 1.25-1.55(\mathrm{~m}$, $\left.54 \mathrm{H}, \mathrm{CH}_{3}-\underline{\mathrm{CH}}_{2}-\underline{\mathrm{CH}}_{2}-\mathrm{CH}_{2}, \mathrm{CH}-\underline{\mathrm{C}}_{2}\right)$, 1.55-1.75 (m, 24H, $\left.\mathrm{CH}_{3}-\mathrm{CH}_{2}-\mathrm{CH}_{2}-\mathrm{CH}_{2}\right), 2.60-2.96$ (m, 24H, $\mathrm{CH}_{2} \mathrm{~S}$ ), 3.07 and 3.09 (2 br.s., 6H, =C-Cㅍ-CH), 3.34 (br.s., 6H, =C-CH-Cㅂ), 5.50 (br.s., $6 \mathrm{H}, \mathrm{H}-\mathrm{C}=\mathrm{C}-\mathrm{H}), 6.63(50 \%)$ and $6.65(50 \%)\left(2 \mathrm{~s}, 3 \mathrm{H}, \mathrm{S}_{2} \mathrm{C}=\mathrm{CH}-\mathrm{C}\right), 7.10-7.20(\mathrm{~m}, 3 \mathrm{H}, \mathrm{S}-\mathrm{C}=\mathrm{CH}-\mathrm{C}$ $+\mathrm{C}_{6} \underline{\mathrm{H}}_{3}$ arom.). ${ }^{13} \mathrm{C} N M R\left(\mathrm{CDCl}_{3}\right) \delta: 14.6\left(\mathrm{CH}_{3}\right), 22.9\left(\mathrm{CH}_{3}-\mathrm{CH}_{2}\right), 30.1\left(\mathrm{CH}_{3}-\mathrm{CH}_{2}-\mathrm{CH}_{2}-\mathrm{CH}_{2}\right)$, $31.4\left(\mathrm{CH}_{3}-\mathrm{CH}_{2}-\underline{\mathrm{CH}_{2}}-\mathrm{CH}_{2}\right), 36.9\left(\mathrm{CH}_{2} \mathrm{~S}\right), 47.8$ (=C- $\left.\underline{\mathrm{CH}}-\mathrm{CH}\right), 48.9$ (=C-CH- $\left.\underline{\mathrm{H}}\right), 50.4$ (=C-CH$\left.\mathrm{CH}-\underline{\mathrm{CH}}_{2}\right), 115.5\left(\mathrm{~S}_{2} \mathrm{C}=\underline{\mathrm{CH}}-\mathrm{Ar}\right), 118.4$ and $119.2(\mathrm{~S}-\mathrm{C}=\underline{\mathrm{CH}}-\mathrm{C}), 124.8\left(\mathrm{~S}{ }_{2} \underline{\mathrm{C}}=\mathrm{C}-\mathrm{C}\right), 126.8$ and $127.0\left(\mathrm{~S}_{2} \mathrm{C}=\mathrm{CS}_{2}\right), 128.7\left(\mathrm{~S}_{2} \mathrm{C}=\underline{\mathrm{C}}-\mathrm{C}\right), 133.4,134.3,134.9,135.1,137.6,137.7(=\mathrm{C}-\mathrm{CH}=\underline{\mathrm{CS}} 2, \mathrm{H}-$ $\mathrm{C}=\mathrm{C}-\mathrm{H}, \mathrm{S}-\underline{\mathrm{C}}=\mathrm{CH}-\underline{\mathrm{C}}, \underline{\mathrm{C}}_{6} \mathrm{H}_{3}$ arom.). Elemental analysis for $\mathrm{C}_{135} \mathrm{H}_{168} \mathrm{~S}_{30}$ (2748.48) calcd. C 58.90, H 6.15, S 34.95; found : C 57.67, H 6.02, S 34.30.

Compound (44). A solution of TTF $43\left(77 \mathrm{mg} ; 2.8 .10^{-5} \mathrm{~mol}\right)$ in $o$-dichlorobenzene $(3 \mathrm{~mL})$ was refluxed for $15 \mathrm{~min}$. The solvent was distilled using a Kugelrohr apparatus $\left(50^{\circ} \mathrm{C}, 9 \mathrm{~mm} \mathrm{Hg}\right)$. Extended-TTF was isolated as red bordeaux crystals (71 mg; quantitative yield). M.p. $=92-95^{\circ} \mathrm{C}$. MS Maldi-Tof m/e : $2554\left(\mathrm{M}^{+}\right)$. Elemental analysis for $\mathrm{C}_{120} \mathrm{H}_{150} \mathrm{~S}_{30}(2550.34)$ calcd. C 56.42, $\mathrm{H}$ 5.92, S 37.66; found : C 56.13, H 5.84, S 37.52.

\section{Supplementary Information Available}

X-ray crystallography data for compound 26 as CIF files.

\section{Acknowledgements}

We gratefully acknowledge Dr. J. Orduna and Pr. J. Garín (University of Zaragoza, Spain), Dr. C. Rovira and Dr. D. Amabilino (ICMAB Bellaterra, Spain) for mass spectrometry analyses, as well as Prof. A. Riou and M. Allain for X-ray structure determination. This work was supported by a grant from the MENRT for N. Gautier. MS thanks the Institut Universitaire de France (IUF) for financial support.

\section{References and Footnotes}

1. Chem. Rev. 2004, 104, issue 11, Molecular Conductors (Thematic issue), Batail, P. Ed.

2. (a) Bryce, M.R. J. Mater. Chem., 1995, 5, 1481; (b) Fabre, J.-M. J. Solid State Chem., 2002, 168, 367; (c) Frère, P.; Skabara, P. Chem. Soc. Rev., 2005, 34, 69.

3. Yamada, J.; Sugimoto, T., Eds. TTF Chemistry. Fundamentals and applications of tetrathiafulvalene, Springer Verlag, 2004. 
4. (a) Bendikov, M.; Wudl, F.; Perepichka, D.F. Chem. Rev. 2004, 104, 4891. (b) Jeppesen, J.O.; Nielsen, M.B.; Becher, J. Chem. Rev. 2004, 104, 5115. (c) Fabre, J.-M. Chem. Rev. 2004, 104, 5133.

5. Gorgues, A.; Hudhomme, P.; Sallé, M. Chem. Rev. 2004, 104, 5151.

6. Iyoda, M.; Hasegawa, M.; Miyake, Y. Chem. Rev. 2004, 104, 5085.

7. (a) Sato, M.; Gonnella N. C.; Cava, M. P. J. Org. Chem., 1979, 44, 930. (b) Ishikawa, K.; Akiba, K.; Inamoto, N.; Tetrahedron Lett., 1976, 3695. (c) Akiba, K.; Ishikawa, K.; Inamoto, N; Synthesis, 1977, 861. (d) Akiba, K.; Ishikawa, K.; Inamoto, N; Bull. Chem. Soc. Jpn, 1978, 51, 2674. (e) Ishikawa, K.; Akiba, K. Bull. Chem. Soc. Jpn, 1978, 51, 3695. (f) Moore, A.J.; Bryce, M.R.; Synthesis, 1991, 26.

8. Garín, J.; Orduna, J.; Uriel, S.; Moore, A. J.; Bryce, M. R.; Wegener, S.; Yufit, D. S.; Howard, J. A. K Synthesis, 1994, 489.

9. Blanchard, P.; Sallé, M.; Duguay, G.; Jubault, M.; Gorgues A. Tetrahedron Lett., 1992, 33, 2685.

10. Andreu, R.; Garín, J.; Orduna J.; Saviron, M.; Uriel, S. Synth. Metals, 1995, 70, 1113.

11. Andreu, R.; Garín, J.; Orduna J.; Saviron, M.; Cousseau, J.; Gorgues, A.; Morisson, V.; Nozdryn, T.; Becher, J.; Clausen, R. P.; Bryce, M. R.; Skabara, P. J.; Dehaen, W. Tetrahedron Lett., 1994, 35, 9243.

12. Lee, R. A.; Donald, D. S. Tetrahedron Lett., 1997, 22, 3857.

13. (a) Gorgues, A.; Batail, P.; Le Coq, A. J. Chem. Soc., Chem. Commun. 1983, 405. (b) Sallé, M.; Gorgues, A.; Jubault, M.; Boubekeur, K. ; Batail, P. Tetrahedron, 1992, 48, 3081. (c) Sallé, M.; Gorgues, A.; Jubault, M.; Boubekeur, K.; Batail, P; Carlier, R. Bull. Soc. Chim. Fr, 1996, 133, 417.

14. Hudhomme, P.; Le Moustarder, S.; Durand, C.; Gallego-Planas, N.; Mercier, N.; Blanchard, P.; Levillain, E.; Allain, M.; Gorgues, A.; Riou, A. Chem. Eur. J. 2001, 7, 5070.

15. (a) Hansen, T.K.; Lakshmikantham, M.V.; Cava, M.P.; Metzger, R.M.; Becher, J. J. Org. Chem., 1991, 56, 2720; (b) Bryce, M.R.; Coffin, M.A.; Clegg, W. J. Org. Chem., 1992, 57, 1696; (c) Nguyen, T.-T.; Gouriou, Y.; Sallé, M.; Frère, P.; Jubault, M.; Gorgues, A.; Toupet, L.; Riou, A. Bull. Soc. Chim. Fr, 1996, 133, 301.

16. (a) Yamashita, Y.; Suzuki, T.; Miyashi, T. Chem. Lett., 1989, 1607. (b) Saito, K.; Sugiura, C.; Tanimoto, E.; Saito, K.; Yamashita, Y. Heterocycles, 1994, 38, 2153.

17. (a) Gautier, N.; Dumur, F.; Lloveras, V.; Vidal-Gancedo, J.; Veciana, J.; Rovira, C.; Hudhomme, P. Angew. Chem. Int. Ed. 2003, 42, 2765. (b) Dumur, F.; Gautier, N.; GallegoPlanas, N.; Şahin, Y.; Levillain, E. ; Mercier, N.; Hudhomme, P.; Masino, M.; Girlando, A.; Lloveras, V.; Vidal-Gancedo, J.; Veciana, J.; Rovira, C. J. Org. Chem. 2004, 69, 2164.

18. Boulle, C.; Desmars, O.; Gautier, N.; Hudhomme, P.; Cariou, M.; Gorgues, A. Chem. Commun., 1998, 2197.

19. (a) Boulle, C.; Cariou, M.; Bainville, M.; Gorgues, A.; Hudhomme, P.; Orduna J.; Garín, J. Tetrahedron Lett., 1997, 38, 81. (b) Boulle, C.; Rabreau, J.-M.; Hudhomme, P.; Cariou, M.; Jubault, M.; Gorgues, A.; Orduna J.; Garín, J. Tetrahedron Lett., 1997, 38, 3909. (c) Gautier, 
N.; Mercier, N.; Riou, A.; Gorgues, A.; Hudhomme, P. Tetrahedron Lett., 1999, 40, 5997.

(d) Gautier, N.; Cariou, M.; Gorgues, A.; Hudhomme, P. Tetrahedron Lett., 2000, 41, 2091.

(e) Kreher, D.; Cariou, M.; Liu, S-G.; Levillain, E.; Veciana, J.; Rovira, C.; Gorgues, A.; Hudhomme, P. J. Mater. Chem., 2002, 12, 2137.

20. Jeppesen, J.O.; Takimiya, K.; Jensen, F.; Brimert, T.; Nielsen, K.; Thorup, N.; Becher, B. J. Org. Chem., 2000, 65, 5794.

21. Hudhomme, P.; Liu, S.-G.; Kreher, D.; Cariou M.; Gorgues, A. Tetrahedron Lett., 1999, 40, 2927.

22. Bredereck, H.; Simchen, G., Griebenow, W. Chem. Ber., 1973, 106, 3732.

23. (a) Parg, R.P.; Kilburn, J.D. Synthesis, 1994, 195. (b) Fanghänel, E.; Beye, N.; Wegner, R.; Bierwisch, J.; Herrmann, L.; Van Hinh, L.; Gebler, B.; Strunk, K. Molecular Engineering for Advanced Materials, ed. Becher, J. and Schaumburg, K. NATO ASI Series C 456, 1995, 295. (c) Fanghänel, E.; Strunk, K; Gärtner, U. J. Prakt. Chem., 1996, 338, 146

24. A similar reaction using trimethylphosphite has been reported for the conversion of thionolactone to the corresponding lactone; Ayral-Kaloustian, S.; Agosta, W.C. Synth. Commun., 1981, 11, 1011.

25. Fourmigué, M.; Johannsen, I.; Boubekeur, K.; Nelson, C.; Batail, P. J. Am. Chem. Soc., 1993, 115, 3752.

26. Batail, P; Boubekeur, K.; Fourmigué, M.; Gabriel, J.-C. Chem. Mater, 1998, 10, 3005.

27. Crystal Structure Analysis, Molecular Enraf-Nonius (MolEN), 1990, Delft Instruments Xray Diffraction B. V. Rontnenweg 12624 BD Delft The Netherlands. 